\title{
18. FORAMINIFERA FROM THE LOWER CRETACEOUS AND UPPER JURASSIC OF THE NORTHWESTERN ATLANTIC
}

\author{
PRELIMINARY NOTE \\ Hanspeter Luterbacher, Esso Production Research-European, 33-Bègles (France)
}

\section{INTRODUCTION}

During Leg 11 (Miami-Hoboken) of the Deep Sea Drilling Project, deposits of early Cretaceous and late Jurassic age were penetrated at four sites. Three of them (Sites 99, 100, 101) are situated in the BlakeBahama Abyssal Plain to the north and east of San Salvador (Bahama Islands), whereas Site 105 is near northern end of the Hatteras Abyssal Plain approximately 600 kilometers to the east of Cape Hatteras (Figure 1). For exact locations, lithologic descriptions and other details, reference is made to the individual Site Reports in this volume.

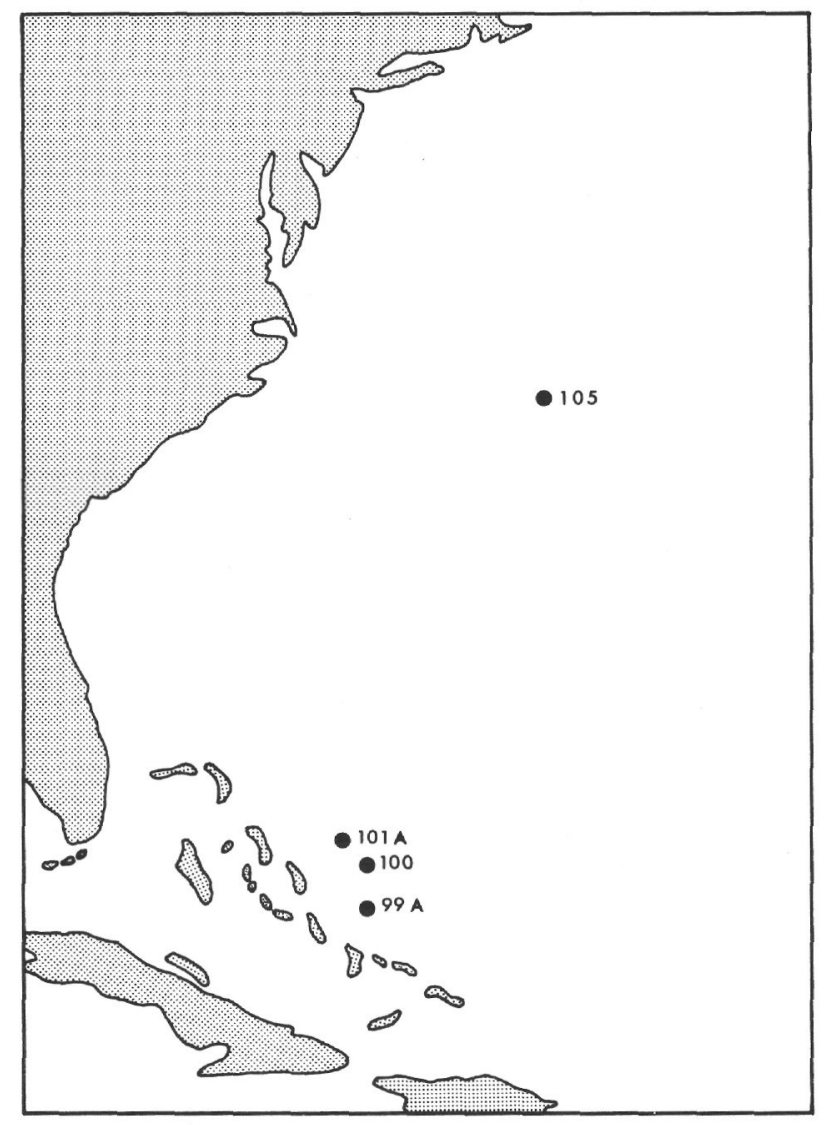

Figure 1. Location map.
This chapter represents a preliminary note on the foraminifera found in the washed residues; in addition, a few other groups of fossils are taken into consideration. The few months available between the end of the cruise and the deadline for the submission of this manuscript did not allow a very detailed study of the, in places, rich and varied foraminiferal faunas. Such a comprehensive work would also exceed the scope of an initial report. In this preliminary note, I intend merely to give a general description of the fossils found in the washed residues (mainly in the form of distribution charts), discuss some aspects of the foraminiferal assemblages, and illustrate a few of the more conspicuous forms. In view of the importance of the finding of late Jurassic and early Cretaceous foraminifera during Leg 11, I have started their monographic description, which will give the necessary taxonomic discussions and illustrations. It should be emphasized that the determinations given in this preliminary note are provisional. Many of them will undergo changes and, hopefully, some of them will become more precise as work proceeds.

A few groups of fossils are discussed in separate chapters in this volume (O. Renz: megafossils, H. J. Oertli: ostracodes, H. Hess: crinoids, and R. Lehmann: thin sections).

\section{Acknowledgements}

I am greatly indebted to the Deep Sea Drilling Project for the very unexpected opportunity to take part in Leg 11 , and to the scientific staff and technicians of this leg for their collaboration during the two months at sea. Esso Production Research-European provided the necessary time and technical assistance necessary to complete this initial report.

Part of the faunas was worked out during a stay at the Geology Department in Basel, where I had an opportunity to make use of the library facilities and to compare the faunas with collections from the Jurassic and Cretaceous of western Europe and the Caribbean area. This opportunity proved to be very useful and I am indebted to Drs. H. P. Laubscher and L. Hottinger for their kind hospitality. Dr. D. Bernoulli discussed with me aspects of the environmental interpretation. 
In addition, I received help and advice from the following people: Mrs. J. Aubert and Dr. H. J. Oertli (Pau), Drs. I. Premoli Silva, M. B. Cita (Milan), Drs. K. Pozaryska, W. Posaryski (Warsaw), I. V. Dolitzkaya (Moscow), Drs. M. Reichel, D. Bernoulli, L. Hottinger, H. Fischer, O. Renz, H. G. Kugler, P. Jung, Mrs. T. Manger (Basel), Dr. H. M. Bolli (Zurich), Dr. F. Allemann (Bern), Dr. H. J. Wall (Edmonton), Dr. J. Wilcoxon (La Habra), Dr. C. W. Poag (College Station), Drs. R. Lehmann and J. Ferrer (Bègles). To all of them I want to express my sincere thanks.

The scanning electron scope micrographs were kindly provided by Drs. H. J. Oertli, H. E. Franz, H. M. Bolli and D. Bernoulli.

\section{AGE SIGNIFICANCE OF FAUNAL ASSEMBLAGES}

\section{Early Cenomanian-Late Albian}

(Site 101A, Core 4A; Site 105, Cores 11, 12)

Characteristic species:

Rotalipora apenninica apenninica (Renz)

Rotalipora apenninica primitiva Borsetti

Praeglobotruncana delrioensis (Plummer)

Planomalina buxtorfi (Gandolfi)

Hedbergella trocoidea (Gandolfi)

Hedbergella amabilis Loeblich and Tappan

At Holes 101 A and 105, the upper part of the interval with "black clay" contains a poor, but often excellently preserved assemblage of planktonic foraminifera which is characterized by the presence of Rotalipora apenninica apenninica and Planomalina buxtorfi (see Plate 5, Figures 1, 2 and 3). Noteworthy is the presence of extremely spiny Hedbergella in a rather uncommon state of preservation (Plate 6, Figure 1).

The faunal assemblage listed above can be correlated with beds corresponding to the "Vraconian". This "stage" is considered to be part of the late Albian by most European workers. However, the DSDP Paleontology and Biostratigraphy Panel has placed the "Vraconian" arbitrarily in the Cenomanian.

\section{Albian to Hauterivian}

(Site 101, Cores 5A-9A?; Site 105, Cores 13-17)

The interval represented by the lower and middle part of the "black clay facies" is in great part void of foraminifera or contains only rare and scattered lagenids and primitive arenaceous foraminifera which are not age-diagnostic.

The core catcher of Core 5 at Site 101 contains Hedbergella infracretacea (Glaessner), Höglundina (?) sp. (Plate 5, Figure 5 and 6), and Gavelinella sp. aff. G. barremiana, and might therefore not be older than Aptian.

Core 17 of Site 105 is transitional between the "black clay facies" and the underlying light-gray limestone with intercalations of carbonaceous clay. It contains a poorly preserved faunule of very small planktonic foraminifera tentatively assigned to the species Hedbergella sp. cf $H$. infracretacea (Glaessner), $H$. hauterivica (Subbotina), H. globigerinelloides (Subbotina), Globigerinelloides ultramicrus (Subbotina). Similar faunules of very small and primitive planktonic foraminifera, with varying species names, are reported from beds ranging from late Hauterivian to early Aptian of various regions.

\section{Hauterivian to late Valanginian}

(Site 105, Core 18)

Characteristic species:

Lamellaptychus seranonis (Coquand)

Lamellaptychus angulocostatus (Peter)

Lamellaptychus angulocostatus atlanticus (Hennig)

Lamellaptychus angulocostatus atlanticus radiatus (Trauth)

Lamellaptychus joides Renz (n. sp.)

Lenticulina ouachensis ouachensis (Sigal)

Lenticulina ouachensis multicella Bartenstein, Bettenstaedt \& Bolli

The separation of a Hauterivian-late Valanginian interval at Site 105 is based on the presence of an aptychi fauna in Section 5 of Core 18 (see chapter by O. Renz in this volume).

The range of Lenticulina ouachensis ouachensis (Plate 6, Figure 2), a species of worldwide distribution, is given as early Valanginian to early Aptian age by Moullade (1966) and as late Hauterivian to early Aptian by Bartenstein and Bettenstaedt (in "Arbeitskreis...", 1962). Lenticulina ouachensis multicella occurs from the late Valanginian to the early Aptian (Moullade, 1966).

\section{Valanginian (?)}

(Site 101, Core 10A; Site 105, Cores 19-21)

\section{Characteristic species:}

Dorothia praehauteriviana Dieni \& Massari.

The lowermost core of Hole 101A and Cores 19 through 21 of Hole 105 contain Dorothia praehauteriviana (Plate 1, Figures 20-24; Plate 5, Figures 7 and 8), a species known from the Valanginian of Sardegna. It has been described hitherto only from one locality and its stratigraphic value is therefore not established. The occurrence of this conspicuous species is used to correlate the base of Hole $101 \mathrm{~A}$ with Hole 105. 


\section{Valanginian to Tithonian}

Site 100, Core 1; Site 105, Cores 22-23)

Characteristic species:

Vaginulina sp. aff. V. biochei (Terquem)

Lenticulina nodosa (Reuss)

Lenticulina subalata (Reuss)

Frondicularia simplicissima Ten Dam

Tintinnopsella carpathica (Murgeanu and Filipescu)

Remaniella sp. aff. $R$. cadischiana (Colom)

Calpionella alpina Lorenz

Calpionella elliptica Cadisch

Calpionellopsis sp. aff. C. oblonga (Cadisch)

Calpionellopsis sp. aff. C. simplex (Colom)

Nannoconus spp.

"Stomiosphaera"

The rare and patchy foraminiferal faunas found in the lower and middle part of the interval with light-gray coccolith ooze and limestone at Sites 100 and 105 are not sufficiently rich and varied to allow an age assignment. This interval is therefore mainly dated on the basis of the occurrence of calpionellids (isolated loricae in Core 1 at Site 100; in thin sections at Site 105).

Section 5 of Core 100-1 contains very rare isolated loricae of calpionellids, which were tentatively assigned by R. Lehmann to Remaniella sp. aff. $R$. cadischiana, Calpionellopsis sp. aff. C. oblonga, $C$. sp. aff. $C$. simplex, Calpionella sp. aff. C. alpina, and Tintinnopsella sp. aff. T. carpathica (see Plate 7, Figure 5 through 10; Plate 8, Figure 1 through 4). However, the identification of calpionellids is based on thin sections and the identification of isolated loricae is somewhat arbitrary. All loricae are of a considerably larger size than those usually found in thin sections. The calpionellid association found in Core 1 of Site 100 is indicative of a Berriasian age (e.g., Le Hégarat and Remane, 1968).

The base of the light-gray limestone at Site 105 (Core 33, Section 1) contains Calpionella alpina and Tintinnopsella carpathica in thin sections. This association would be placed in the Alpine-Mediterranean region in the vicinity of the Cretaceous-Jurassic boundary, with preference for the early Berriaisian; but a late Tithonian age cannot be excluded (See chapter by $R$. Lehmann in this volume). This age assignment is in conflict with the ages indicated for the same interval by palynomorphs and calcareous nannoplankton, which suggest a considerably older age (see chapters by D. Habib and J. Wilcoxon in this volume). Judoley and Furrazola-Bermudez (1965) report the coexistence of Calpionella alpina, Tintinnopsella carpathica, Nannoconus spp., and Saccocoma spp. with ammonites of an early to middle Tithonian age in the Artemisa Formation of Cuba and emphasize that the stratigraphic values of calpionellids in Cuba might differ from those known from the Alpine-Mediterranean area. The aptychi found immediately below the last occurrence of calpionellids at Site 105 can be correlated with those from the Artemisa Formation, and indicate a Kimmeridgian-Tithonian age.

\section{Tithonian to Kimmeridgian}

(Site 99, Cores 12A-14A; Site 100, Cores 2-6; Site 105, Cores 33-37).

Characteristic species:

Lamellaptychus rectecostatus crassocostatus Trauth Lamellaptychus lamellosus (Parkinson)

Lamellaptychus beyrichi (Oppel)

Lamellaptychus murocostatus Trauth

Laevilammelaptychus of Haploceras aporus (Oppel)

Punctaptychus monsalvensis Trauth

Punctaptychus punctatus (Voltz)

Aspidoceras sp. cf. A. pawlowi Burckhardt

Saccocoma sp. cf. S. quenstedti Sieverts-Doreck (ms)

Saccocoma sp. cf. S. schattenbergi Sieverts-Doreck (ms)

Saccocoma sp. cf. S. subornata Sieverts-Doreck (ms)

Bairdia (Akidobairdia) farinacciae Oertli

Brotzenia sp. ex gr. B. parastelligera (Hofker)

Brotzenia sp. aff. B. uhligi (Myatliuk)

Brotzenia spp. ex gr. B. mosquensis (Uhlig)

The age attribution of the interval of red and green calcareous mudstone with flow structures and, in places, graded beds and clasts of white limestone, is based on the aptychi found in Cores 33 through 37 at Site 105 and on the finding of Aspidoceras sp. in Core 37. The aptychi indicate a Kimmeridgian to Tithonian age based on occurrences in Europe, Africa, and the Caribbean area (see chapter by $\mathrm{O}$. Renz in this volume).

The remains of the pelagic crinoid Saccocoma, which are found in variable amounts scattered throughout this interval, are comparable to species described from the middle to late Oxfordian and from the Kimmeridgian of western Europe (see chapter by H. Hess in this volume). The correlation of the lowermost part of the section at Hole $99 \mathrm{~A}$ with this interval is based on the occurrence of Saccocoma sp. cf. S. quenstedti.

The ostracod faunas of Jurassic deposits in a facies comparable to that of the Upper Jurassic of the northwestern Atlantic are not yet sufficiently known to be used for a further subdivision of the late Jurassic (see chapter by H. J. Oertli in this volume).

The foraminiferal faunas are dominated by "primitive" arenaceous forms and lagenids. Most of the forms can 


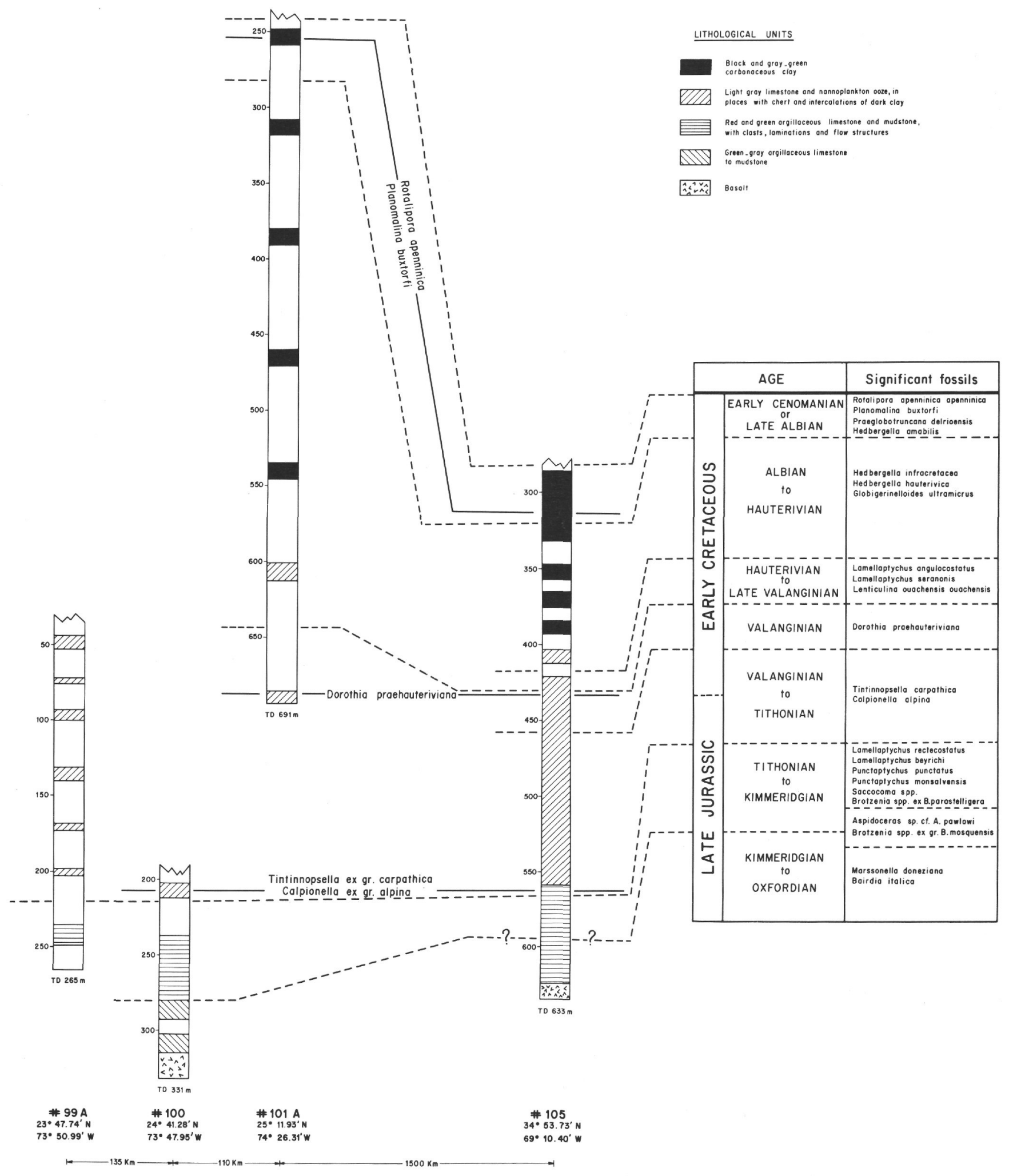

Figure 2. Correlation of the Lower Cretaceous and Upper Jurassic of Sites 99, 100, 101, and 105. 
be readily identified with species described from the Upper Jurassic of Europe. "For the Jurassic the use of index forms is not generally possible in foraminiferal work. There is usually a close homeomorph to be found outside the Jurassic and dating, in our present state of knowledge, can be only achieved by rather complex evaluation of entire assemblages" (W. J. Clarke, DSDP Core Description Manual). This statement is even more true for Jurassic foraminiferal faunas from a facies and an area in which little or no previous work has been done and where no regional subdivisions of the Jurassic based on foraminifera are available. Published data on smaller foraminifera from the Jurassic of the western hemisphere are too scarce and too patchy to establish a faunal succession which could be compared with those known from Europe. The difficulties of such a comparison are, in addition, compounded by the introduction of new species which, in great part, overlap with European species. Data on the Jurassic foraminifera from the Grand Banks are, unfortunately, not available.

The foraminifera from the deposits overlying the basalt at Sites 100 and 105 broadly indicate a late Jurassic age, but a further subdivision of this interval based on foraminiferal evidence has not yet been attempted. For the distribution of the different genera and species, reference is made to the range charts.

The species of Brotzenia found in Cores 36 through 38 at Site 105 indicate an Oxfordian to Kimmeridgian age. Brotzenia mosquensis (Plate 4, Figures 11, 12 and 13), is generally not recorded from beds above the Oxfordian. However, in Core 37 it occurs together with Aspidoceras sp. cf. A. pawlowi, an ammonite species known from the Kimmeridgian of Mexico.

\section{Kimmeridgian (?) to Oxfordian (?)}

(Site 100, Cores 7-10; Site 105, Cores 38-40)

At Site 100, the lowermost four cores above basalt consist of a greenish-gray argillaceous limestone to mudstone, which indicates a more quiet sedimentary regime than that during the deposition of the overlying red mudstone. Palynomorphs and calcareous nannoplankton indicate an Oxfordian age for this interval and for Cores 38 to 40 at Site 105. The foraminiferal faunas of this interval are not significantly different from those of the overlying mudstone. Minor differences are probably a result of environmental changes.

The following species are found in the lowermost four cores immediately overlying the basalt at Site 100 , but not in the oldest assemblages from Site 105: Bigenerina jurassica (Haeusler) (Plate 1, Figure 2; Plate 5, Figures 9 and 10), Bigenerina arcuata (Haeusler) (Plate 1,
Figure 11), Bolivinopsis helvetojurassicus (Kübler and Zwingli) (Plate 1, Figure 10), Marssonella doneziana Dain (Plate 1, Figures 16 and 17), Trocholina transversarii Paalzow (Plate 2, Figures 8 and 10), Lenticulina polonica (Wisniowski), Marginulina minuta (Terquem) (Plate 3, Figure 30), and "Planularia" pseudoparallela E. and I. Seibold (Plate 3. Figures 19 and 20).

Cores 38 to 40 of Site 105 are tentatively assigned to the same interval, since they are below the Kimmeridgian ammonite in Core 37.

No evidence can be derived from the study of the foraminiferal faunas for the presence of deposits older than late Jurassic at the sites drilled during Leg 11.

\section{FAUNAL RELATIONS AND ENVIRONMENTAL INTERPRETATION}

The distribution charts from Sites 100, 101 and 105 show the samples examined, the frequency of the microfauna in the washed residues, the preservation, the presence and frequency of Radiolaria, ostracodes, foraminifera and other organic remains.

In order to allow a rough evaluation, the foraminifera were subdivided into four groups. (a) "Primitive foraminifera": This group includes mainly the simply structured arenaceous foraminifera. A few primitive genera with calcareous tests are also placed arbitrarily in this group. Only the forms with distinctly agglutinated tests were determined as "Ammodiscus", whereas forms with vitreous or indeterminate wall structure were placed in "Spirillina". (b) Lagenids: The use of genera and subgenera in lagenids varies considerably from author to author (e.g., Lenticulina-Astacolus, Vaginulina-Vaginulinopsis). In this preliminary note, no attempt is made to consider this problem. Generic attributions of species are those found in the literature used for the determination. It seemed more important to illustrate some of the more frequent forms than to discuss their taxonomic status. (c) Others: This heading includes the benthonic foraminifera not included in (a) and (b). (d) Planktonic foraminifera.

The Lower Cretaceous and Upper Jurassic cored during Leg 11 in the northwestern Atlantic can be roughly subdivided into four lithologic units:

1. Black and green carbonaceous clay (early Cenomanian/late Albian to Hauterivian; Holes 101A, 105)

2. Light gray limestone and nannoplankton ooze, in places with chert and intercalations of dark clay (Hauterivian to Valanginian-Tithonian; Holes 99A, 100, 101A, 105) 
DISTRIBUTION OF MICROFOSSILS (WASHED RESIDUES) IN THE UPPER JURASSIC - SITE 100 , LEG XI

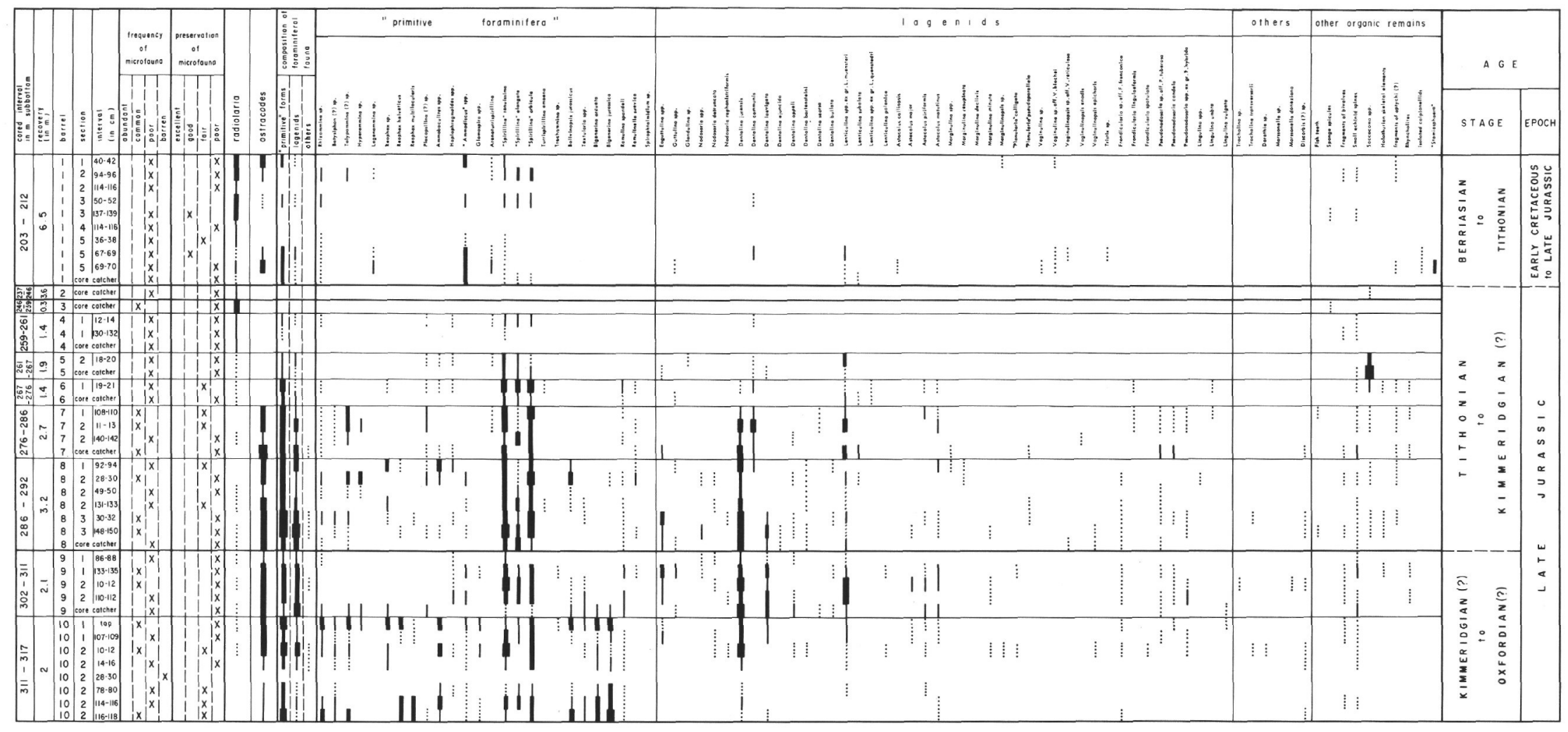

1 trequent I common 1 rore i very rore

Distribution Chart 1. Distribution of microfossils (washed residues) in the Upper Jurassic-Site 100, Leg 11. 
DISTRIBUTION OF MICROFOSSILS (WASHED RESIDUES) IN THE LOWER CRETACEOUS - SITE $101 \mathrm{~A}$, LEG XI

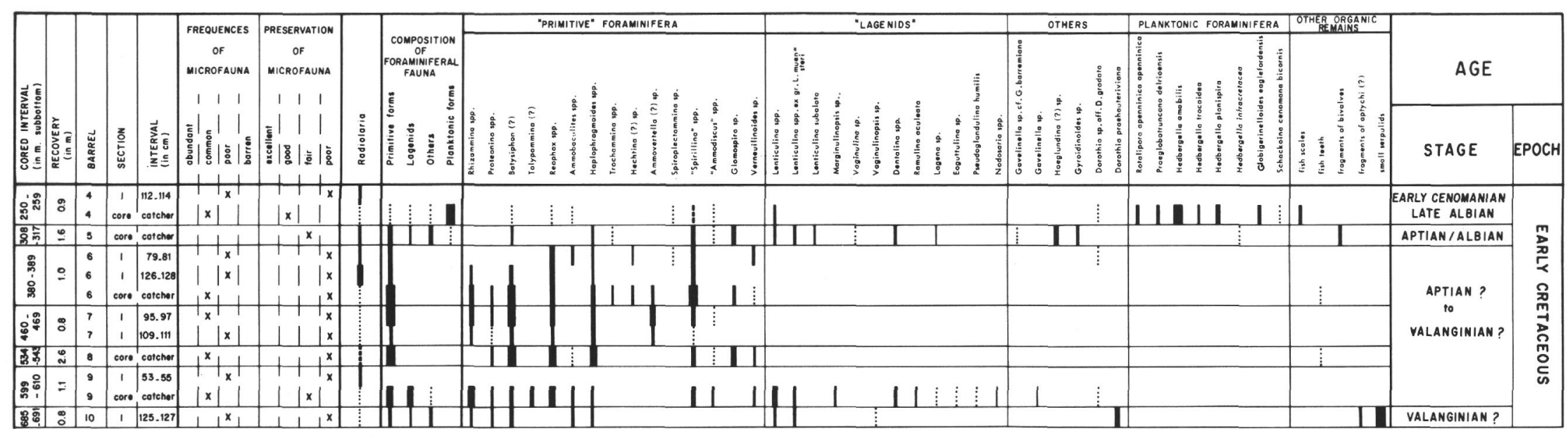

- Freavent I common I Rare ivery rore

Distribution Chart 2. Distribution of microfossils (washed residues) in the Lower Cretaceous Site 101 (Hole 101A) Leg 11. 
DISTRIBUTION OF MICROFOSSILS (WASHED RESIDUES) IN THE LOWER CRETACEOUS AND UPPER JURASSIC

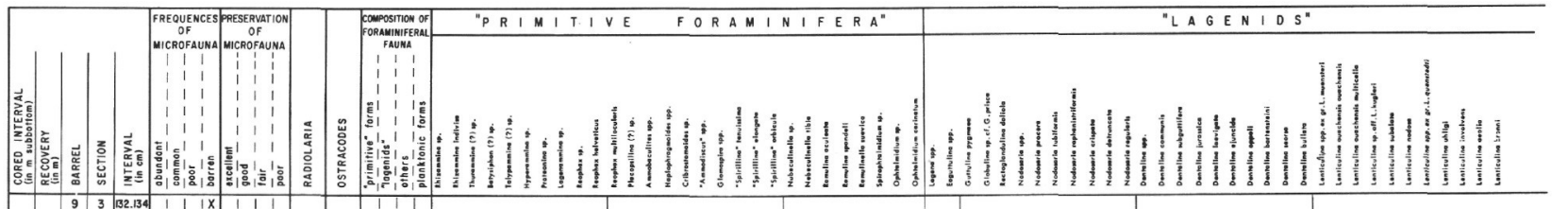

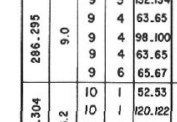

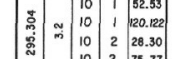

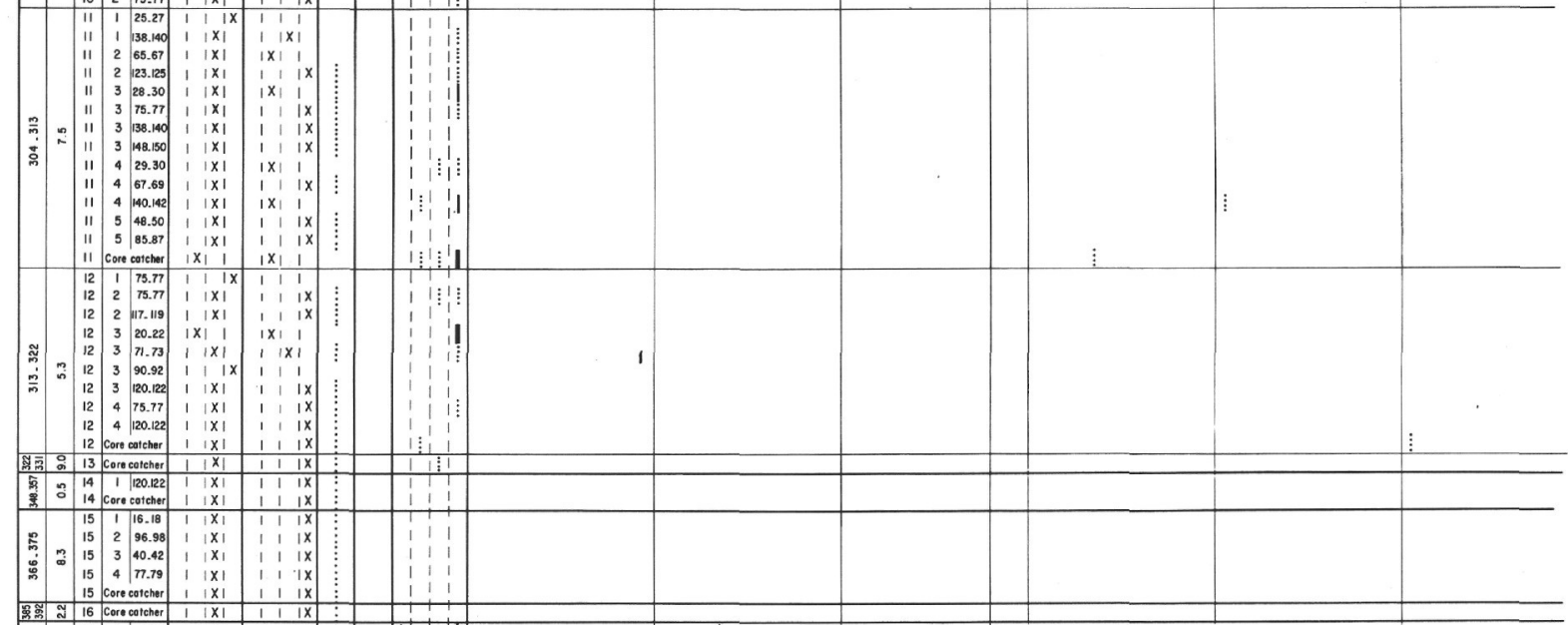

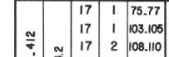

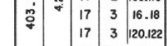

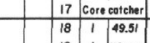

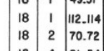

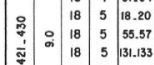

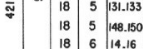

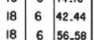

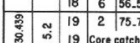

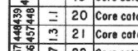

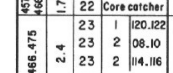

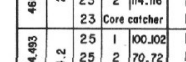

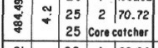

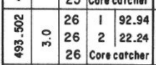

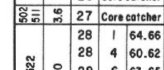

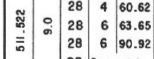

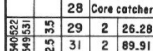

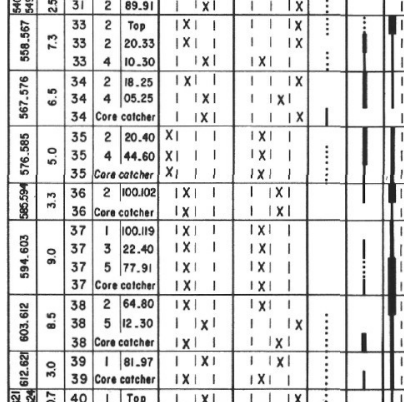

I trequent

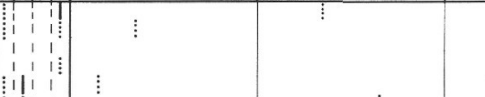

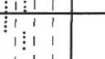

:

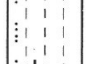

$\begin{array}{llll}1 & 1 & 1 \\ 1 & 1 & 1 \\ 1 & 1 & 1 \\ 1 & 1 & 1 \\ 1 & 1 & 1\end{array}$

:

$\begin{array}{l:l:ll}1 & 1 & 1\end{array}$

$\vdots$

$\vdots$

:

: : : :

I I

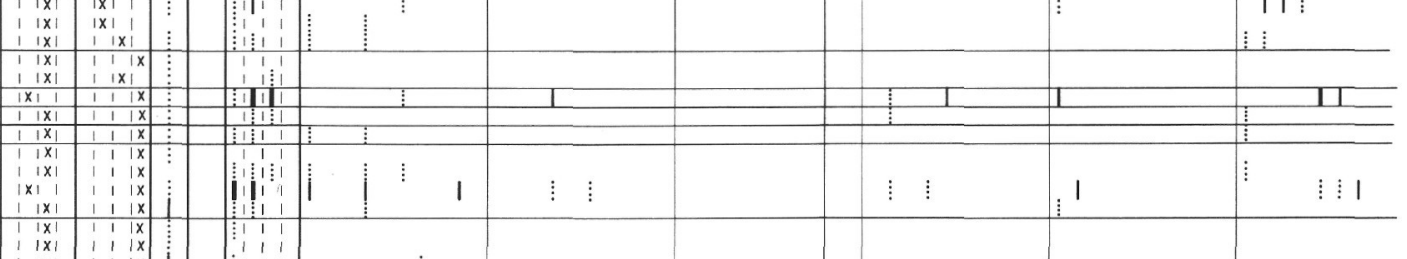

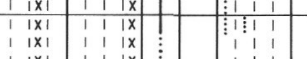

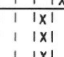

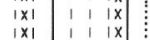

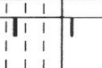

Distribution Chart 3. Distribution of microfossils in the Lower Cretaceous and Upper Jurassic-Site 105, Leg 11. 
SITE 105, LEG XI.

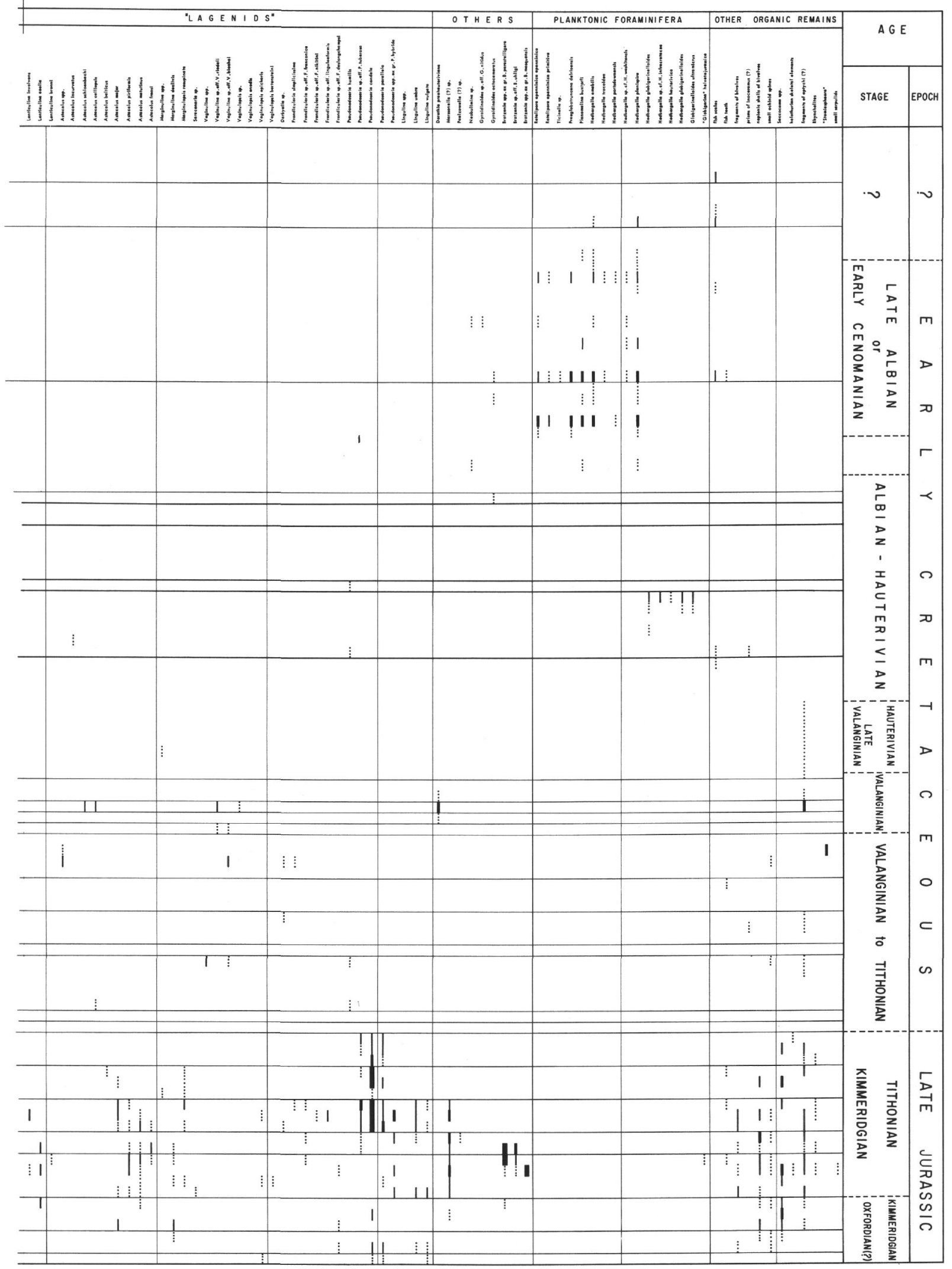

Distribution Chart 3. Distribution of microfossils in the Lower Cretaceous and Upper Jurassic-Site 105, Leg 11. (Cont) 
3. Red and green argillaceous limestones and calcareous mudstones, with clasts, laminations and flow structures (Tithonian-Kimmeridgian to Kimmeridgian-Oxfordian; Holes 99A, 100, 105)

4. Green-gray argillaceous limestone to mudstone (Oxfordian; Hole 100)

\section{Black and Green Carbonaceous Clay}

The washed residues from the interval, which is mainly represented by black and dark green carbonaceous clays and shales, are all poor and often barren. Rare Radiolaria, often pyritized, are frequently the only microfossils present (especially at Site 105). The upper part is rich in fish scales (cf. "fish scale zone" at Cenomanian/Albian boundary in western Canada; e.g., Wall 1967). The occurrence of foraminifera is restricted to a few thin intercalations with higher carbonate content (see also Berger, 1969). Planktonic foraminifera are restricted to the upper part (Cores $101 \mathrm{~A}-4,5,105-11,12)$. They are common at Hole $101 \mathrm{~A}$, but rare to very rare at Site 105 . Noteworthy is the finding of very rare oogonia of Characea at Site 101 in Core 4A, which are derived from brackish or fresh water deposits.

The composition of the scarce foraminiferal faunas found at Hole $101 \mathrm{~A}$ recalls closely the poor assemblages known from the variegated shales of the lower and middle part of the "Scaglia variegata," especially those of the interval with the "Scisti a Pesci" in the southern Alps, the dark intercalations in the "Scisti a Fucoidi" and the "Strato bituminoso" in the "Scaglia bianca" of the Central Appennines (see chapter by D. Bernoulli in this volume). All these deposits with comparable foraminiferal faunas are inserted in open marine limestones and shales. They represent probably periods of poor oxygenation without major fluctuations of the water depth.

At Site 101, the only foraminifera found in the lower and middle part of the "black clay interval" (Cores 6A to $8 \mathrm{~A}$ ) belong mainly to the genera Rhizammina, Bathysiphon, Reophax, Haplophragmoides, Ammovertella (?), and "Spirillina." Recent faunas exclusively composed of simply-structured arenaceous foraminifera with a comparable generic composition ("Rabdammina faunas" in Brouwer 1965) are reported from depths below 2000 meters (for example, Saidova, 1969). According to Saidova, faunas with only arenaceous foraminifera are found in the tropical and subtropical parts of the Pacific at depths exceeding 4500 and 5000 meters. Also, the absence of calcareous benthonic foraminifera would suggest deposition below the carbonate compensation depth. The early Cretaceous black and green carbonaceous clays at Holes $101 \mathrm{~A}$ and 105 may therefore have been deposited in a deep-bathyal to possibly even an abyssal environment.
Light Gray Limestone and Nannoplankton ooze, with Thin Intercalations of Carbonaceous Clay and Chert

The fossil content of the washed residues from this interval, which is attributed to the Neocomian to Tithonian, is always poor to very poor or barren. Radiolaria are found in variable amounts throughout this interval. The foraminifera are mainly represented by simply-structured arenaceous forms and a few lagenids.

Cores 17 and 18 at Site 105 are transitional toward the "black clay" facies. Core 17 contains a fauna of very small planktonic foraminifera, which are associated with "primitive" arenaceous foraminifera and very rare lagenids. The composition of the assemblage recalls somewhat those from the Valanginian-Hauterivian of the Fosse vocontienne in southeastern France (for example, Moullade, 1966) and also the microfaunas described from the Toco and Cuche Formations in Trinidad (Bartenstein, Bettenstaedt and Bolli, 1957).

Cores $9 \mathrm{~A}$ and $10 \mathrm{~A}$ at Site 101, which belong to the upper part of the same lithologic unit, contain similar foraminiferal faunas. Noteworthy is the presence of clusters of small serpulids in Core 10A (Plate 6, Figures 3 through 6; see also Bernoulli and Renz, 1970, p. 586).

The middle to lower parts of the light gray nannoplankton ooze at Site 105 (Cores 24 to 32) are much poorer in foraminifera, which are, in addition, restricted to a few levels (see distribution chart). Core 1 at Site 100 is an exception to this paucity of microfauna, since it contains a fairly rich assemblage of ostracodes, Radiolaria and "primitive" foraminifera, whereas lagenids are rare. The sediments of this core might have been deposited at a lesser depth than the rest of this lithologic unit. The presence of very rare isolated loricae of calpionellids in this core is an outstanding feature. Calpionellids occur also at the base of this lithologic unit at Site 105, whereas they are absent or preserved only as "ghosts" throughout most of the rest of it (see chapter by R. Lehmann in this volume and discussion in Cita, 1970).

The light gray limestones, which are largely composed of coccoliths, are very similar to the "Maiolica" facies of the Neocomian and Tithonian of the AlpineMediterranean area. Following the argumentation developed by Colom (1967) for the "Maiolica" deposits, they are considered to represent deep-bathyal, but probably not abyssal deposits. The predominance of simply-structured arenaceous foraminifera in the poor faunas, and the absence of calcareous foraminifera, other than rare lagenids, would conform with this conclusion. The absence of well-preserved calpionellids in the upper and middle parts and their appearance at the base might indicate a diminution in water-depth in the lower part of this lithologic unit. 
BREGGIA SECTION (SOUTHERN SWITZERLAND)

(after Gandolfı.1942, Luterbocher.1965, and unpublished sources)
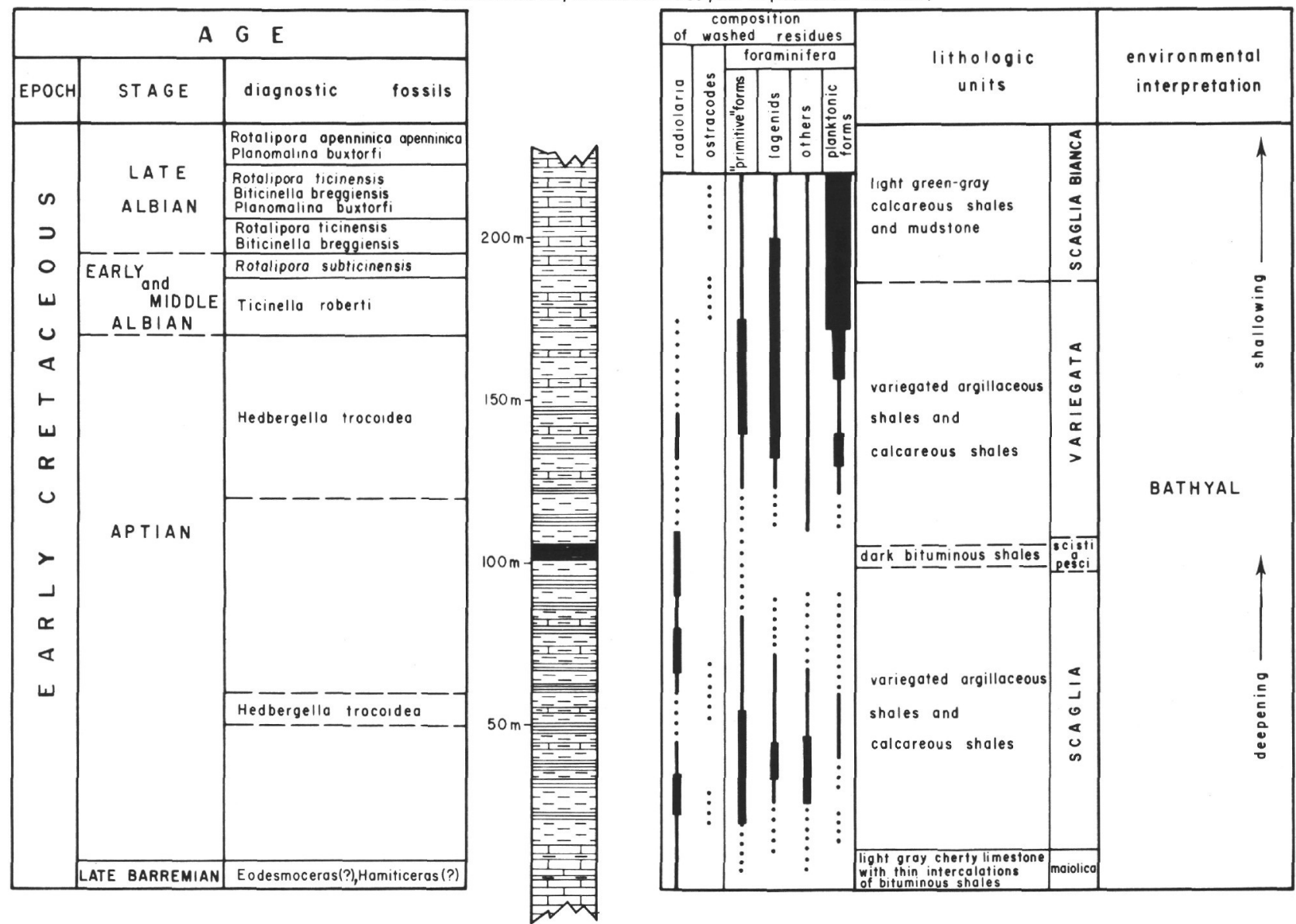

Figure 3. Lower Cretaceous of the Breggia section (southern Switzerland).

SITE 100

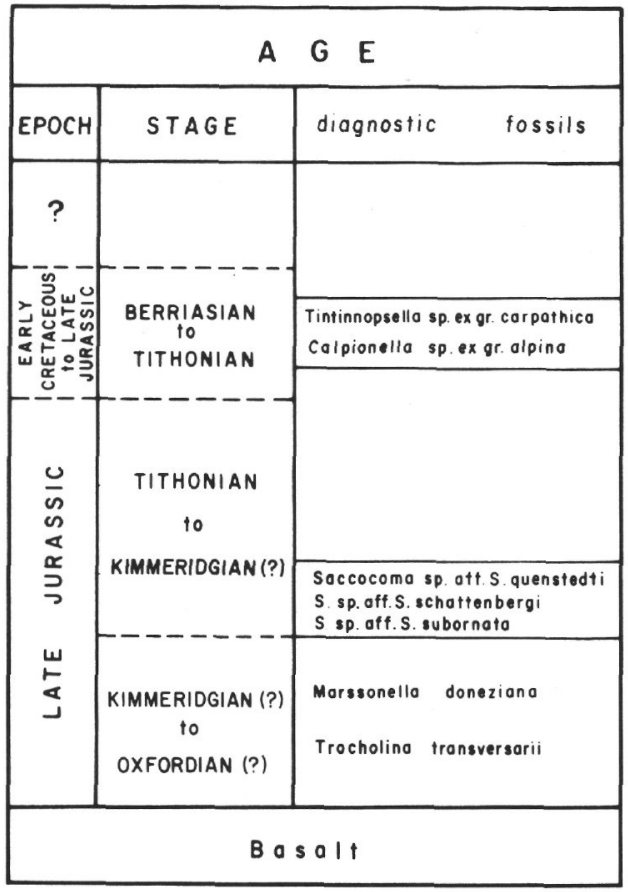
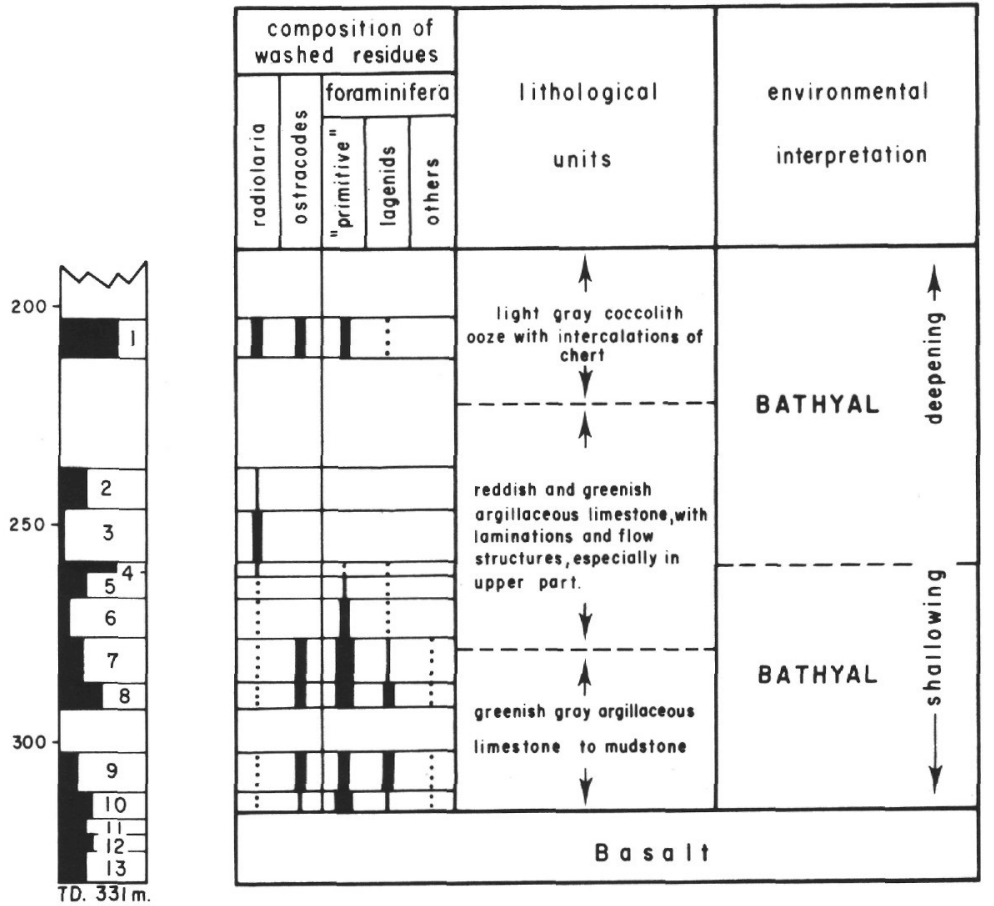

Figure 4. Upper Jurassic of Site 100. 
SITE IOI A
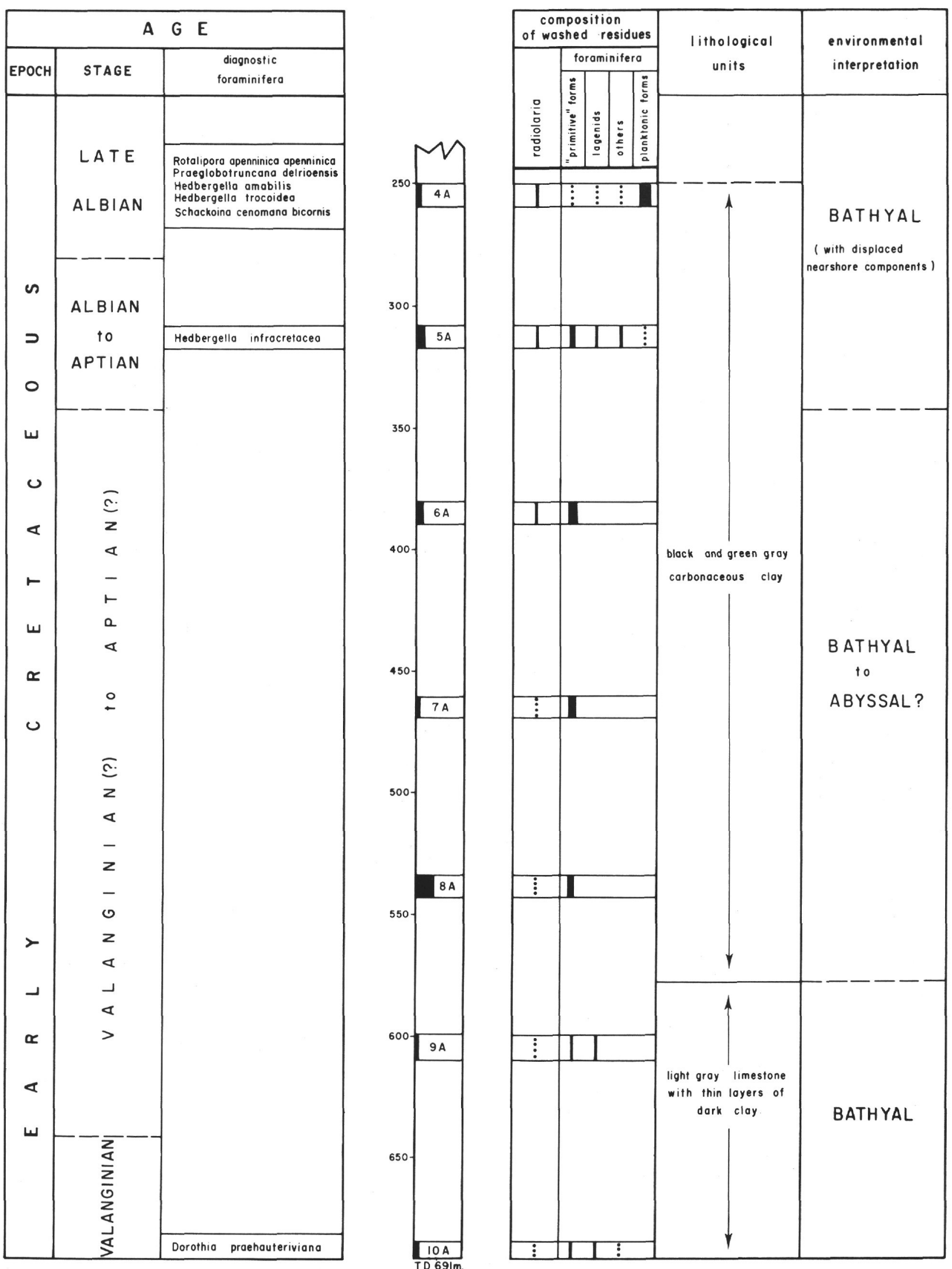

Figure 5. Lower Cretaceous of Site 101 (Hole 101A). 


\section{Red and Green Argillaceous Limestone and Calcareous Mudstone, with Clasts, Laminations, and Flow Structures}

The foraminiferal faunas of Cores 33 to 40 at Site 105 are generally fairly rich and reasonably well preserved. They consist mainly of simple arenaceous foraminifera and lagenids. A few intervals are relatively rich in Radiolaria, ostracodes, Saccocoma spp., aptychi, and other organic remains. A few samples are almost exclusively composed of epistominids; others contain a considerable number of adherent forms (for example, Nubeculinella) or are dominated by primitive miliolids (Ophtalmidium).

The microfaunas from the corresponding interval at Site 100 are generally poorer and composed almost exclusively by simple arenaceous forms and lagenids. Representatives of "Spirillina" dominate most of the samples. For more details, reference is made to the distribution charts of Sites 100 and 105.

Gordon (1970) reviewed the biogeographic distribution of Jurassic foraminifera and distinguished five broad types of assemblages:

\section{A. Shelf Assemblages}

1. Nodosariid and Nodosariid mixed assemblages

2. Dominantly simple arenaceous assemblages

3. Calcareous benthonic foraminifera other than Nodosariids conspicuous

\section{B. Tethyan Assemblages ${ }^{1}$}

1. Complex arenaceous species dominant

2. Planktonic assemblages

"Shelf assemblages" in the sense of Gordon are the faunas known from North America (for a review see, for example, Wall 1960; Gordon 1970) and Europe, but also those from the Sinai, Madagascar, Australia and New Zealand. (Extensive references to literature on Jurassic foraminifera may be found in Bielecka 1960, Lutze 1960, Espitalié and Sigal 1963, Oesterle 1968, Winter 1970, and others.)

The assemblages of the red calcareous mudstone and argillaceous limestones of Site 105 would belong to groups A1, A2, and A3 as distinguished by Gordon. Those of the corresponding interval at Site 100 would represent groups $\mathrm{A} 1$ and $\mathrm{A} 2$.

\footnotetext{
${ }^{1}$ The term "Tethys assemblages" chosen by Gordon is somewhat unfortunate, since all assemblages of type $A$ are also known from the area of the ancient Tethys, although very little is yet published on them.
}

The temptation is great to assign the foraminiferal assemblages from the Upper Jurassic of the northwestern Atlantic to the "shelf assemblages" from the Western Interior of North America and to those from Europe, especially to the assemblages from the marly sediments, which were probably deposited in middle to outer neritic environments (for example, "Argovian" of the eastern Swiss Jura Mountains, the Jurassic of the Polish Lowlands). The assemblages dominated by epistominids from Cores 105-36, 37 could be compared with similar ones from nearshore deposits in Europe (for example, Adlenian of the Swiss Jura Mountains, Dogger alpha of southwestern Germany); the adherent arenaceous foraminifera compared with those from the Lower Malm of the "Aargauer Jura" in Switzerland, the Steinmǔhl Kalke in Lower Austria, the Kimmeridgian of Franconia or the type-locality of this stage in southern England.

Such a comparison may, however, be fallacious. The environmental significance of Jurassic foraminifera is as yet very poorly known (see Funnel, 1967). The very few papers dealing with ecologic aspects discuss specialized environments (such as, Seibold and Seibold 1953). Based on available data, variability among the foraminifera during the Jurassic was much smaller than during later periods (according to Loeblich and Tappan 1964 the number of known Jurassic foraminiferal genera is 140 ; the number of recent genera is 512). This "monotony" of Jurassic foraminiferal assemblages might suggest that certain families and genera may occupy today a smaller number of ecological niches than during the Jurassic.

Practically all literature available on Jurassic foraminifera deals with faunas from shelf seas or immediately adjacent areas. The assemblages of undoubtedly bathyal or even abyssal Jurassic deposits are virtually unknown. A lone exception is a paper by Farinacci (1965) on a foraminiferal fauna from the Upper Jurassic of the Central Appennines. The microfaunas from this level are closely related to those from the Upper Jurassic of the northwestern Atlantic ${ }^{2}$. Lagenids, Saccocoma spp., fragments of Aptychi and other organic remains are very similar. Noteworthy in both assemblages is the great abundance of "Spirillina". A difference is the scarcity of primitive arenaceous foraminifera in the samples from the Appennines, whereas the ostracode faunas are again very similar (see Chapter by H. J. Oertli in this volume). The deposits from which Farinacci's fauna originates are considered to be bathyal (Farinacci, 1965; Bernoulli, 1967). Typical is the presence of aptychi, Radiolaria and Saccocoma. Noteworthy is the absence of large arenaceous foraminifera (for example, Ammobaculites ex gr.

\footnotetext{
${ }^{2}$ Dr. D. Bernoulli kindly provided samples from Farinacci's locality.
} 


\section{SITE 105}
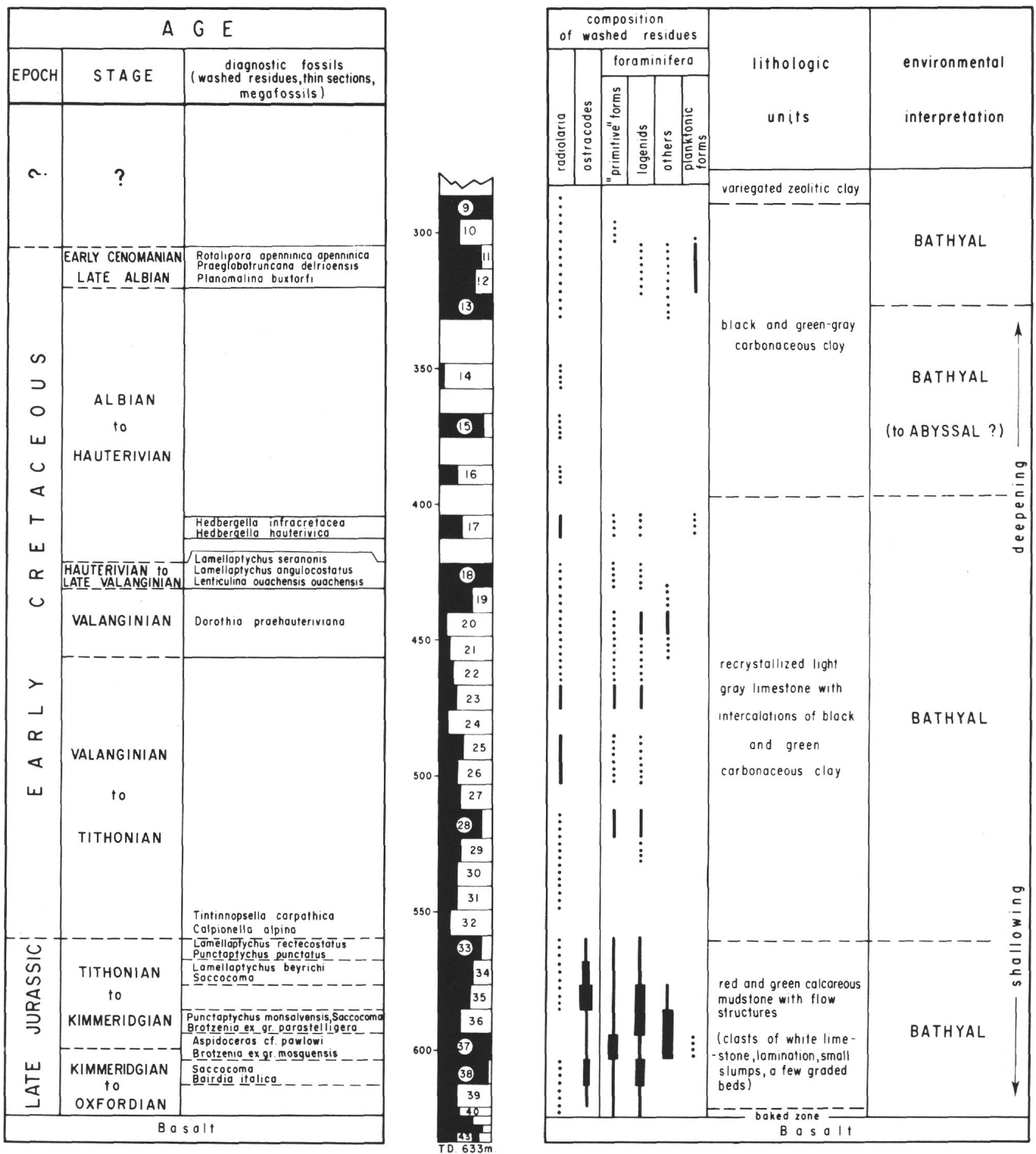

Figure 6. Lower Cretaceous and Upper Jurassic of Site 105. 
A. coprolithiformis, Triplasia), large Frondicularia, and well ornamented ostracodes and ophiurids, which are common in the nearshore deposits of corresponding age.

The clasts of indurated light limestone, which are found in some cores of the interval discussed here contain "Globigerina" helvetojurassica (in Core 105-37), which is not found in the red calcareous mudstone, in which the clasts are embedded. They are very similar to the clasts described by Bernoulli (in Bernoulli and Renz 1970; see also chapter by D. Bernoulli in this volume). Following Bernoulli, it is suggested that these limestones were deposited on highs above the depth of dissolution of planktonic foraminifera and then transported into the red mudstone, which was deposited at greater depths where the tests of planktonic foraminifera were destroyed and only the more resistant lagenids were preserved. The presence of calcareous benthonic foraminifera (lagenids) would, on the other hand, exclude deposition of the red mudstones and limestones below the compensation depth of calcite (see description of sedimentary structures and textures). Redeposition could account for the presence of forms which are considered to be shallow marine (for example, Ophtalmidium). This argument would indicate a depth range corresponding to the bathyal realm for the deposition of the reddish and greenish limestones and mudstones of the Upper Jurassic at Sites 100 and 105 . Such a conclusion is in accordance with the sedimentary structures and textures, which indicate deposition in an area with pronounced submarine topography.

\section{Green-gray Argillaceous Limestone and Calcareous Mudstone}

The lowermost Upper Jurassic sediments at Site 100 (Cores 7 through 10) lack the flow structures, clasts, and graded beds of the overlying red interval, and were probably deposited in a more quiet environment.

The generic composition of the foraminiferal and ostracode assemblages of this unit is close to that of the overlying unit, but such forms as Ophtalmidium and epistominids are missing (see distribution chart). The lowermost assemblages immediately above the basalt consist mainly of "primitive" foraminifera, among which the adherent arenaceous foraminifera reach great importance. These assemblages recall those described by Haeusler (1890; see also Oesterle, 1968) from the Lower Malm of the eastern Swiss Jura Mountains, and may indicate a decrease in water depth.

Very similar assemblages of simply-structured arenaceous foraminifera were recently reported by Holzer (1969) from the Upper Jurassic and Neocomian of Austria from limestones which are considered to be bathyal.

\section{CONCLUSIONS}

A preliminary examination of the foraminifera and a few other fossil groups contained in the washed residues from the Lower Cretaceous and Upper Jurassic recovered during Leg 11 in the northwestern Atlantic allows the precise dating of only a few intervals; only broad age attributions are possible for the others. A combination of the results of the study of fossils in the washed residues with those obtained from palynomorphs, calcareous nannoplankton, and Radiolaria is necessary.

The upper part of the interval with black and green carbonaceous clays at Sites 101 (Hole 101A) and 105 can be dated as late Albian by planktonic foraminifera. The middle and lower parts probably reach into the Neocomian, but precise subdivisions cannot be given based on foraminifera. The poor foraminiferal faunas are compared to present-day deep-bathyal and abyssal assemblages.

At Site 105, the deposits intermediate between the black clay interval and the underlying light gray nannoplankton ooze contain a rich fauna of aptychi of Late Valanginian to Hauterivian age. The rare foraminiferal faunas present in the same interval at Sites 101 (Hole 101A) and 105 concur with this age assignment. The light gray nannoplankton ooze and limestones with intercalations of carbonaceous clays are attributed to the Tithonian to Valanginian, since at the base of Sites 100 and 105 they contain calpionellids which indicate an age close to the Jurassic-Cretaceous boundary. Foraminifera occur only very rarely and are scattered through this interval. Radiolaria are often the only faunal element found in the washed residues. Very similar deposits of the same age in the AlpineMediterranean area are considered to have been deposited at deep-bathyal, but not abyssal depths.

The upper Jurassic red and green argillaceous limestones and calcareous mudstones at Site 105 contain aptychi and an ammonite of Kimmeridgian to Tithonian age. Foraminifers, Saccocoma spp., and ostracodes broadly indicate a late Jurassic age. The lower part of the red mudstones at Site 100 and 105 and the underlying green-gray mudstones at Site 100 may reach into the Oxfordian. The Upper Jurassic foraminiferal assemblages compare well with age-corresponding faunas from North America, and best with a fauna from bathyal deposits of the Alpine-Mediterranean area.

The increase in number of the foraminifera and in their generic and specific variation, the composition of the assemblages, and the presence of a bathyal to outer neritic ostracode fauna in the Upper Jurassic at Sites 100 and 105, suggest a shallowing of the depositional depth towards the base of the sedimentary column in this part of the northwestern Atlantic, but this shallowing probably did not exceed bathyal depths. 


\section{REFERENCES}

Arbeitskreis deutscher Mikropaläontologen, 1962. Leitfossilien der Mikropaläontologie. Berlin (Gebr. Bornträger \& Co.).

Bartenstein, H., Bettenstaedt, F. and Bolli, H. M., 1957. Die Foraminiferen der Unterkreide von Trinidad, B.W.I. Erster Teil: Cuche und Toco Formation. Eclogae Geol. Helv. 50,(2), 5.

Bernoulli, D., 1967. Probleme der Sedimentation im Jura Westgriechenlands und des zentralen Appennins. Verh. Naturf. Ges. Base. 78, 35.

Bernoulli, D. and Renz, O., 1970. Jurassic carbonate facies and new Ammonite faunas from western Greece. Eclogae Geol. Helv. 63(2), 573.

Berger, W. H., 1969. Anaerobic basin sedimentation and differential preservation of planktonic foraminifera. 44th Ann. Meeting Pacific Section Am. Assoc. Petrol. Geologists.

Bielecka, W., 1960. Micropaleontological stratigraphy of the Lower Malm in the vicinity of Chrzanow (southern Poland). Inst. Geol., Prace. 31, 155 p.

Brouwer, J., 1965. Agglutinated foraminifera from some turbidite sequences. Proc. Koninkl. Nederl. Akad. Wetenschap. Ser. B, 68 (5), 309.

Cita, M. B., 1970. Paleoenvironmental aspects of DSDP Legs 1-4. (manuscript).

Colom, G., 1967. Sur l'interprétation des sediments profonds de la zone géosynclinale baléare et subbétique (Espagne). Paleogeogr. Paleoclimatol., Paleoecol. 3 (3), 299.

Espitaliè, J. and Sigal, J., 1963. Contribution à l'étude des foraminifères (micropaléontologie-microstatigraphie) du Jurassique supérieur et du Néocomien du Bassin de Majunga (Madagascar). Ann. Géol. Madagascar. 32, 100p.

Farinacci, A., 1965. I foraminiferi di un livello marnoso nei Calcari diasprigni del Malm (Monti Martani, Umbria). Geol. Romano. 4, 229.

Funnel, B. M., 1967. Foraminifera and Radiolaria as depth indicators in the marine environment. Marine Geol. $5(5 / 6), 333$.

Gordon, W. A., 1970. Biogeography of Jurassic foraminifera. Bull. Geol. Soc. Am. 81 (6), 1689.

Haeusler, R., 1890. Monographie der Foraminiferen der Schweizerischen Transversarius-Zone. Abhandl. Schweiz. Paläont. Ges. 17, 134p.
Hallam, A., 1967. The depth significance of shales with bituminous laminae. Marine Geol. 5 (5/6), 481.

Holzer, H. L., 1969. Agglutinierte Foraminiferen des Oberjura und Neokom aus den östlichen Nördlichen Kalkalpen. Geol. Palaeontol. (Marburg). 3, 97.

Judoley, C. M. and Furrazola-Bermudez, G., 1965. Estratigrafía del Jurasico superior de Cuba. Inst. Cubano Recursos Mineral. Dept. Cientif. Geol., Publ. esp. 3, 32p.

Le Hégarat, G. and Remane, J., 1968. Tithonique et Berriasien de la bordure cévenole. Corrélation des Ammonites et des Calpionelles. Geobios (Fac. Sci. Lyon). 1, 7 .

Loeblich, A. R. jr. and Tappan, H., 1964. Foraminiferal facts, fallacies, and frontiers. Bull. Geol. Soc. Am. 75 (5), 367.

Lutze, G. F., 1960. Zur Stratigraphie und Paläontologie des Callovien und Oxfordien in NordwestDeutschland. Geol. Jahrb. 77, 391.

Moullade, M., 1966. Etude stratigraphique et micropaléontologique du Crétacé inférieur de la "Fosse vocontienne". Documents Lab. Géol. Fac. Sci. Lyon. 15369 p.

Oesterle, H., 1968. Foraminiferen der Typlokalität der Birmenstorfer Schichten, unterer Malm. (Teilrevision der Arbeiten von J. Kubler \& H. Zwingli 1866-1870 und von R. Haeusler 1881-1893). Eclogae Geol. Helv. 61 (2), 695.

Saidova, K. M., 1969. The distribution and ecology of recent benthonic foraminifera in the Pacific Ocean. In Bezrukov, P.L. (editor). Microflora and Microfauna in the Recent Deposits of the Pacific Ocean. Moscow (1zd. Nauka), 120.

Seibold, E. and I., 1953. Foraminiferenfauna und Kalkgehalt eines Profils im gebankten unteren Malm Schwabens. Neues Jahrb. Geol. Paläont., A bhandl. 98 (1), 28.

Wall, J. H., 1960. Jurassic microfaunas from Saskatchewan. Saskatchewan Dept. Mineral Resources, Geol. Div. (53), 229p.

Wall, J. H., 1967. Paleoecology of Cretaceous marine microfaunas in the Rocky Mountain Foothills of Alberta and British Columbia. Res. Council Alberta. Contr. 370 .

Winter, B., 1970. Foraminiferenfaunen des UnterKimmeridge (mittlerer Malm) in Franken. Erlanger Geol. Abhandl., Heft 79. 1. 



\section{PLATE 1}

(All figures approximately $\times 39$ )

Figure $1 \quad$ Tolypammina (?) sp.; 105-39, core catcher

Figure 2 Lagenammina sp.; 100-2, core catcher

Figure 3 Reophax helveticus (Haeusler); 105-39, core catcher

Figure $4 \quad$ Reophax multilocularis Haeusler; 105-35-4, 44-60cm

Figure $5 \quad$ Reophax sp.; 100-10-2, 116-118cm

Figure $6 \quad$ Reophax horridus (Schwager); 100-9, core catcher

Figure $7 \quad$ Haplophragmium sp. aff. H. subaequale (Myatliuk); 100-35-4, 44-60cm

Figure 8 Ammobaculites suprajurassicus (Schwager); 100-8, core catcher

Figure $9 \quad$ Ammobaculites (?) sp.; 105-36-2, 100-102cm

Figure 10 Bolivinopsis helvetojurassicus Kübler and Zwingli, 100-5, core catcher

Figure 11 Bigenerina arcuata Haeusler; 100-10-2, 116-118cm

Figure 12 Bigenerina jurassica Haeusler; 100-10-2, 116-118cm

Figures 13-15 Haplophragmoides (?) sp.; 105-35-2, 20-40cm

Figure 16 Marssonella doneziana Dain;100-9-2, 10-12cm

Figure 17 Marssonella doneziana Dain (transitional form to $M$. jurassica Mityanina); 100-9-1, 133-135cm

Figure 18 Dorothia sp.; 105-20, core catcher

Figure $19 \quad$ Verneuilinoides (?) sp.; 105-23-2, 114-116cm

Figure 20 Dorothia praehauteriviana Dieni and Massari; $105-23-2,114-116 \mathrm{~cm}$

Figures 21-23 Marssonella (?) sp.; 105-37-3, 22-40cm

Figure 24 Dorothia praehauteriviana Dieni and Massari; 105-21, core catcher 

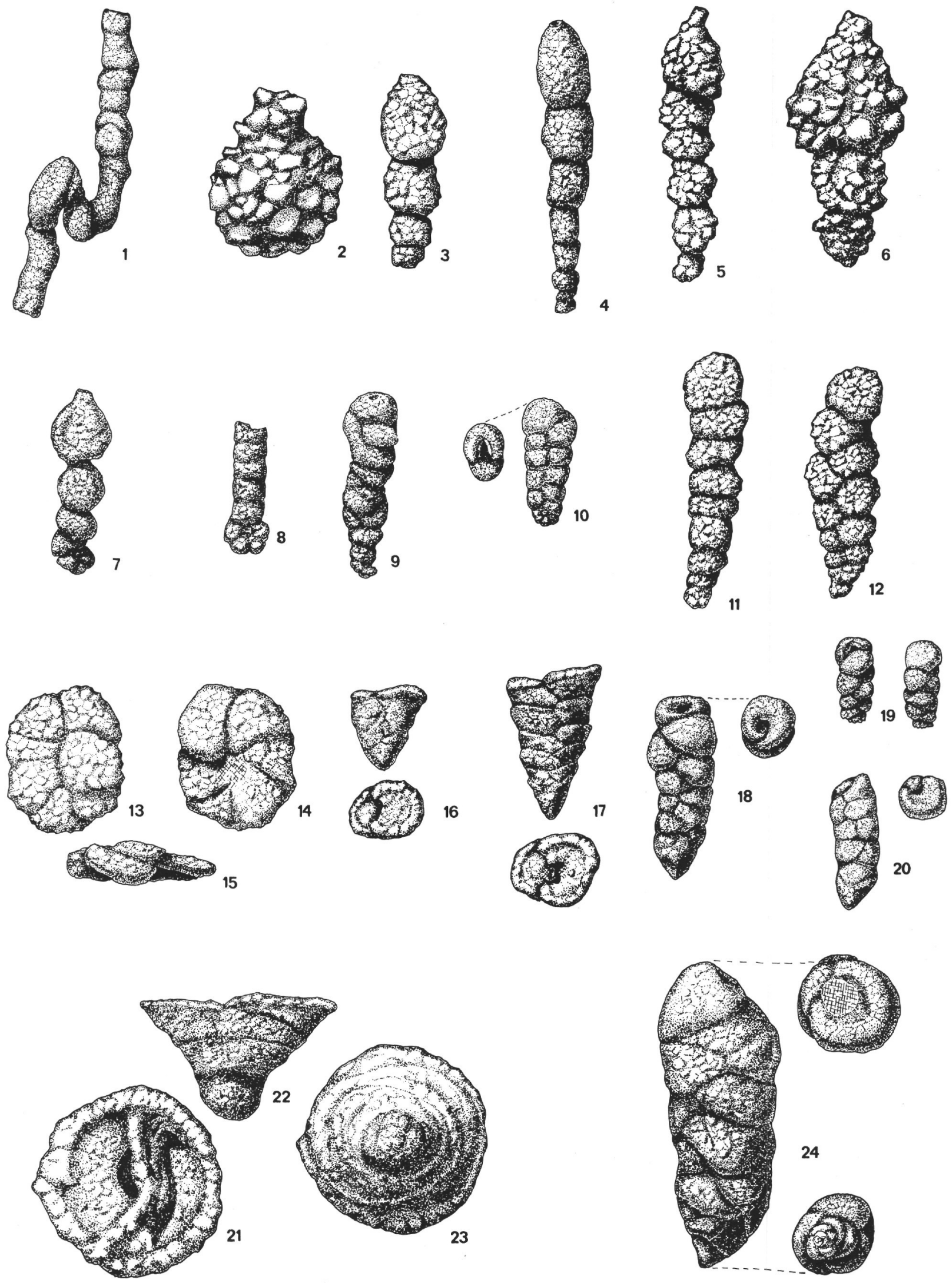


\section{PLATE 2}

(All figures approximately $\times 39$ )

Figures 1-3 Turrispirillina amoena Dain; 100-1, core catcher

Figures 4-6 Glomospira variabilis Kübler and Zwingli; 100-1, core catcher

Figure $7 \quad$ Glomospira sp.; 100-10-2, 10-12cm

Figures 8-10 Trocholina transversarii Paalzow; 100-10-2, 10-12cm

Figures 11-12 Ophtalmidium milioliniformis (Paalzow); 105-37-3, $22-40 \mathrm{~cm}$

Figures 13-15 Spirophtalmidium sp.; 105-37-3, 22-40cm

Figures 16-17 Spirophtalmidium sp.; 105-37-3, 22-40cm

Figures 18-19 Ophtalmidium carinatum Kübler and Zwingli; $105-37-3,22-40 \mathrm{~cm}$

Figure $20 \quad$ Ramulina spandeli Paalzow; 105-36-2, 100-102cm

Figure $21 \quad$ Ramulina nodosarioides Dain; 100-40, top of core

Figure 22 Guttulina pygmaea (Schwager); 105-34-2, $18-25 \mathrm{~cm}$

Figures 23-26 Nubeculinella tibia (Jones and Parker); 105-37-3, $22-40 \mathrm{~cm}$

Figure 27 Eoguttulina biserialis (Terquem); 105-35-2, 20-40cm

Figure 28 Dentalina bartensteini Tappan; 105-35-4, 44-60cm

Figure 29 Nodosaria raphanistriformis (Guembel); 105-35-4, $44-60 \mathrm{~cm}$

Figure $30 \quad$ Nodosaria detruncata Schwager; 105-35-4, 44-60cm

Figure 31 Dentalina sp. aff. D. oppeli Schwager; 105-35-4, $4460 \mathrm{~cm}$

Figure 32 Dentalina bullata Schwager; 105-35-4, 44-60cm

Figure 33 Dentalina seorsa Schwager; 105-35-4, 44-60cm

Figure 34 Dentalina ejuncida Loeblich and Tappan; 105-37-3, $22-40 \mathrm{~cm}$

Figure 35 Dentalina jurensis (Guembel); 100-8, core catcher 

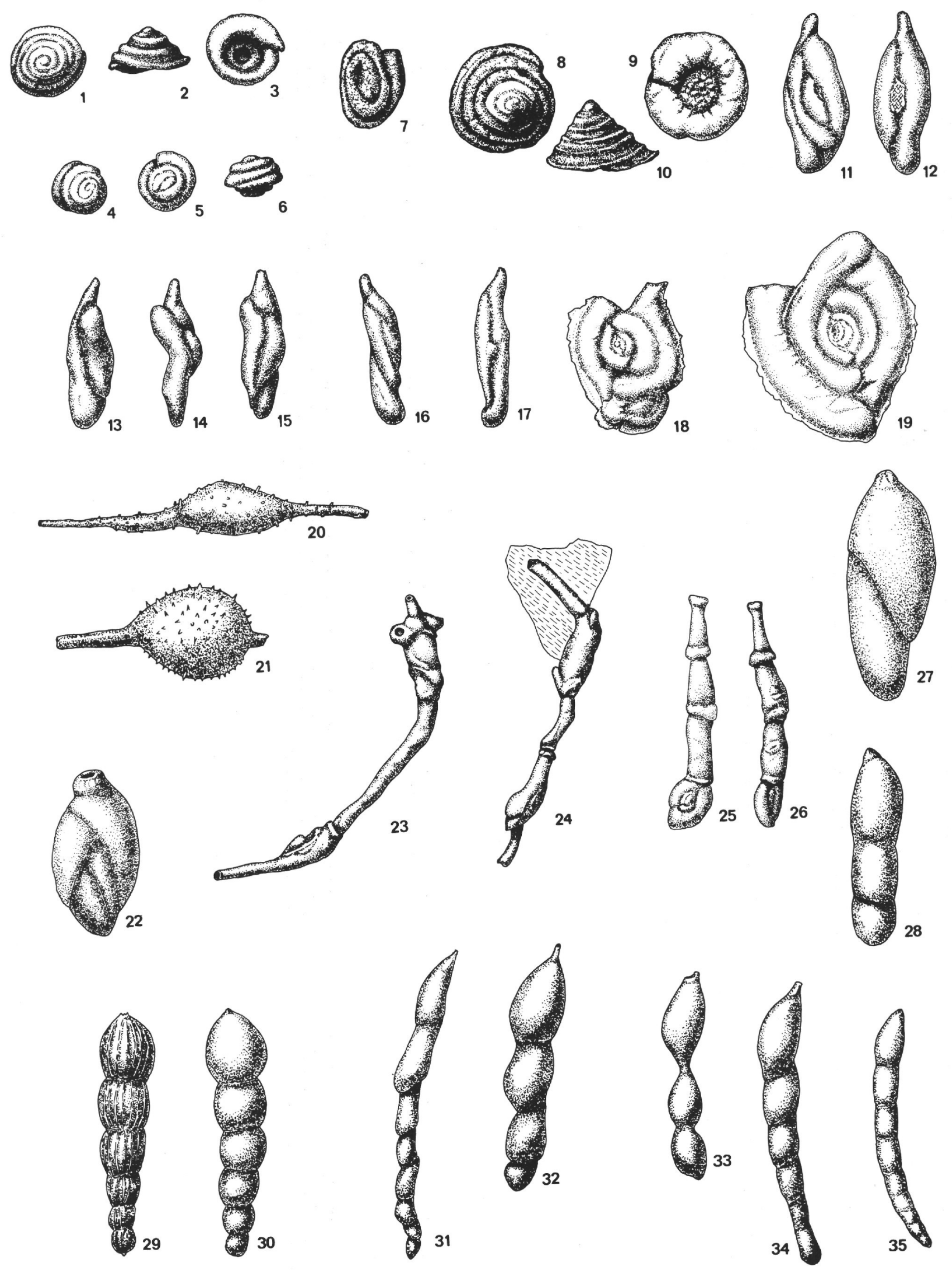


\section{PLATE 3}

(All figures approximately $\times 39$ )

Figures 1-2 Lenticulina quenstedti (Guembel); 105-37-3, $22-40 \mathrm{~cm}$

Figures 3-4 Lenticulina sp. ex gr. L. quenstedti (Guembel); close to "Cristellaria osnabrugensis" in Brückmann 1904; $105-35-2,20-40 \mathrm{~cm}$

Figures 5-6 Lenticulina sp. ex gr. L. quenstedti (Guembel), close to "Cristellaria osnabrugensis" in Brückmann 1904; $105-36-2,100-102 \mathrm{~cm}$

Figures 7-8 Lenticulina involvens (Wisniowski); 105-37-3, $22-40 \mathrm{~cm}$

Figures 9-10 Lenticulina subalata (Reuss); 100-1, core catcher

Figures 11-12 Lenticulina muensteri (Roemer); 100-1, core catcher

Figures 13-14 Lenticulina aeolia Farinacci; 105-37-3, 22-40cm

Figures 15-16 Astacolus matutinus (d'Orbigny); 100-1, core catcher

Figures 17-18 Astacolus fraasi (Schwager); 105-36, core catcher

Figures 19-20 "Planularia" pseudoporallela E. and I. Seibold; 100-7, core catcher

Figure 21 Marginulinopsis resupinata (Schwager); 105-33-2, $20-33 \mathrm{~cm}$

Figures 22-23 Marginulina declivis (Schwager); 105-36, core catcher

Figures 24-25 Vaginulinopsis epicharis Loeblich and Tappan; $105-35-4,44-60 \mathrm{~cm}$

Figures 26-27 Vaginulinopsis enodis Loeblich and Tappan; 105-40, top of core

Figures 28-29 Astacolus balticus (Brückmann); 105-35-2, 20-40cm

Figure 30 Marginulina minuta Terquem; 100-10-2, 10-12cm

Figure 31 Tristix acutangulus (Reuss); 105-23-2, 114-116cm

Figure 32 Vaginulina sp., close to Vaginulina ornithocephala Wisnioswski; 105-28-1, 64-66cm

Figure 33 Falsopalmula deslongchampsi (Terquem); 105-39, core catcher

Figures 34-35 Vaginulina riedeli Bartenstein and Brand; 105-20, core catcher

Figure 36 Frondicularia nikitini Uhlig; 105-35-4, 44-60cm 

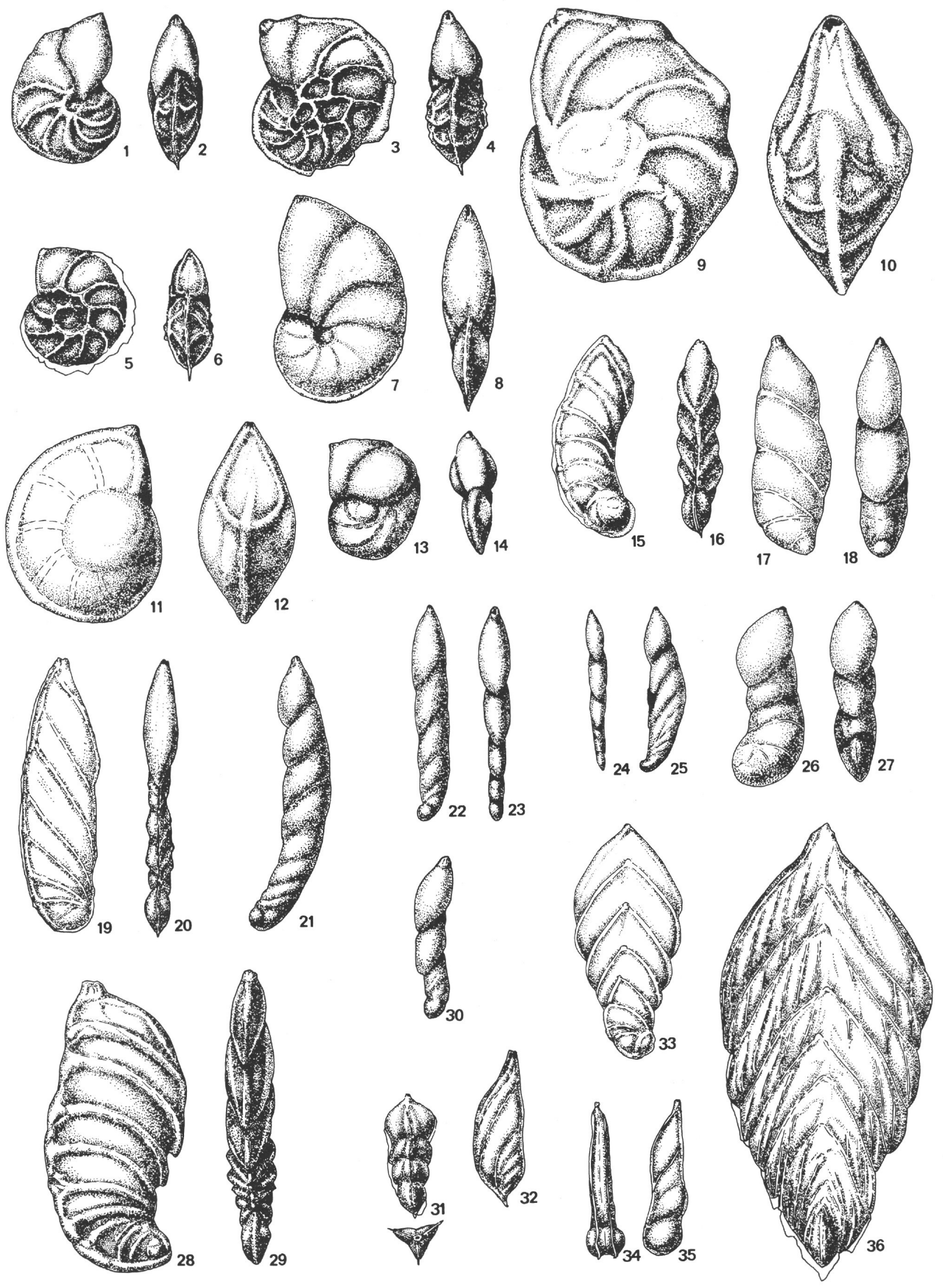


\section{PLATE 4}

(All figures approximately $\times 39$ )

Figure $1 \quad$ Lingulina umbra Farinacci; 105-35-4, 44-60cm

Figure 2 Lingulina vulgata (Bornemann); 105-40, top of core

Figure 3 Frondicularia lingulaeformis Schwager; 100-9, core catcher

Figure $4 \quad$ Pseudonodosaria $\quad$ sp. aff. $\quad$ P. candela (Franke); $105-35-2,20-40 \mathrm{~cm}$

Figure $5 \quad$ Pseudonodosaria candela (Franke); 105-35-4, 44-60 $\mathrm{cm}$

Figure $6 \quad$ Pseudonodosaria sp. aff. P. tuberosa (Schwager); $105-35-2,20-40 \mathrm{~cm}$

Figure $7 \quad$ Pseudonodosaria sp. ex gr. P. hybrida (Terquem and Berthelin); 105-37-3, 22-40cm

Figure $8 \quad$ Frondicularia sp. ex gr. F. franconica Guembel; $100-9-2,110-112 \mathrm{~cm}$

Figure 9 Frondicularia spatulata Terquem; 100-10-2, 10-12cm

Figure 10 Frondicularia rursa (Loeblich and Tappan); 100-8, core catcher

Figures 11-13 Brotzenia sp. ex gr. B. mosquensis (Uhlig); 100-37-3, $22-40 \mathrm{~cm}$

Figures 14-16 Brotzenia sp. aff. B. uhligi (Myatliuk); 105-36, core catcher

Figures 17-19 Brotzenia sp. ex gr. B. parastelligera (Hofker); 105-36, core catcher 

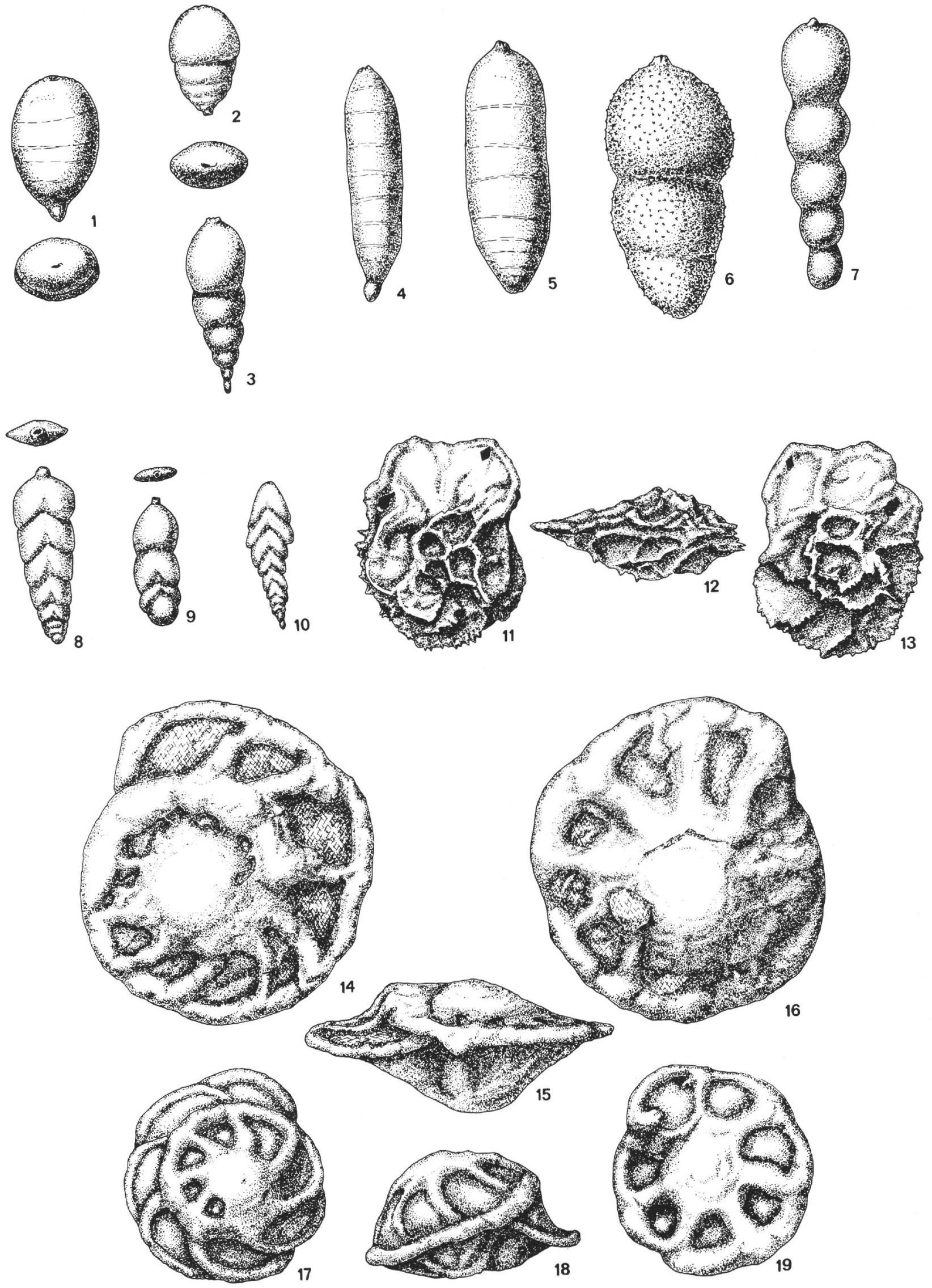
PLATE 5

Figures 1-2 Rotalipora apenninica apenninica (Renz); 105-12-3, 20-22cm; $\times 100$

Figure 3 Planomalina buxtorfi (Gandolfi); 105-11, core catcher; $\times 100$

Figure $4 \quad$ Neobulimina sp.; 105-12-4, 75-77cm; $\times 200$

Figures 5-6 Hoeglundina (?) sp.; 101 A-5, core catcher; $\times 200$

Figures 7.8 Dorothia praehauteriviana Dieni and Massari; 105-20, core catcher; $\times 100$

Figures 9-10 Bigenerina jurassica (Haeusler); 100-10-2, 14-16cm; $\times 100$

Figure $11 \quad$ Rhizammina (?) sp.; 100-7-2, 11-13cm; $\times 100$

Figure 12 Ramulinella suevica Paalzow; 100-8-3, 148-150cm; $\times 100$

Figure $13 \quad$ Spirillina sp.; 105-36-2, 100-102cm; $\times 100$

Figure 14 "Spirillina" elongata Bielecka and Pozaryski; $100-10-2,10-12 \mathrm{~cm} ; \times 100$

Figure $15 \quad$ Ophtalmidium sp.; 105-36-2, 100-102cm; $\times 100$

Figure 16 Ophtalmidium carinatum Kübler and Zwingli; 105-36-2, 100-102cm; $\times 100$

Figure 17 "Spirillina" sp. with Bullopora sp.; 101A-6, core catcher; $\times 100$ 

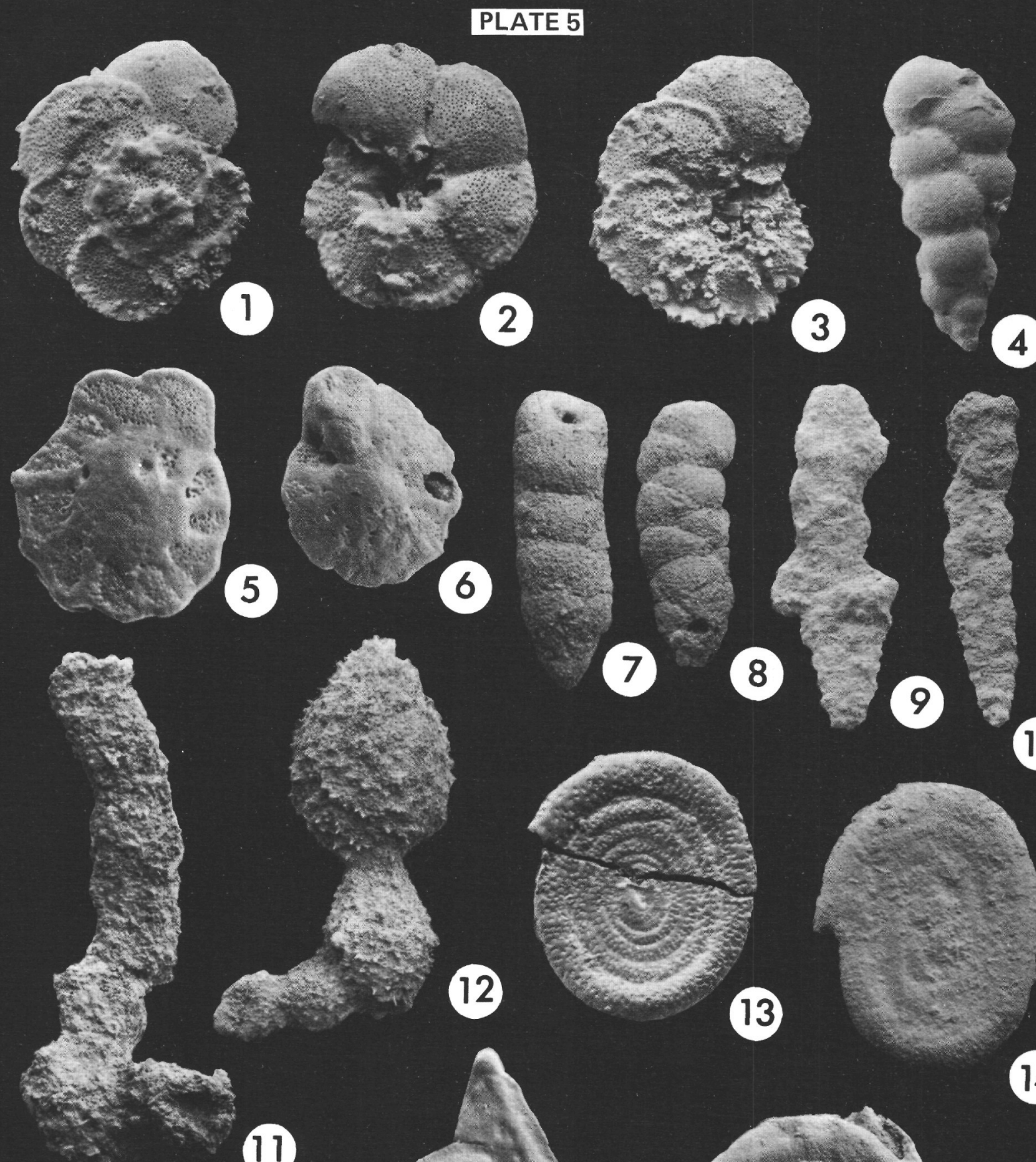

11

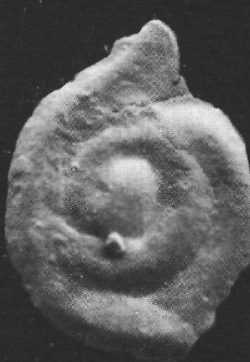

(15)

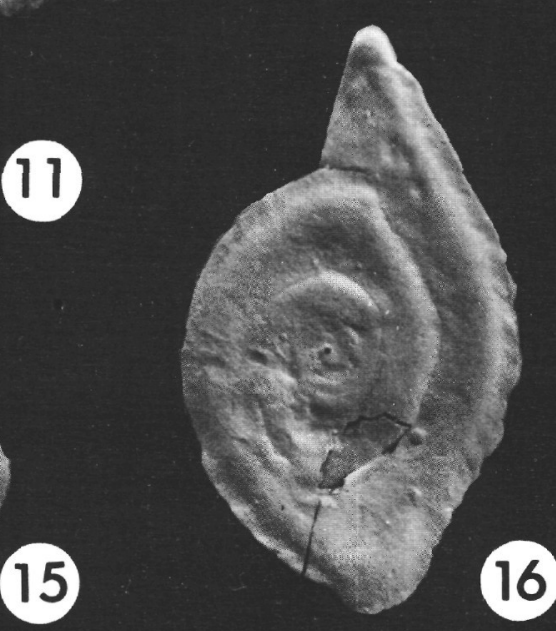

7
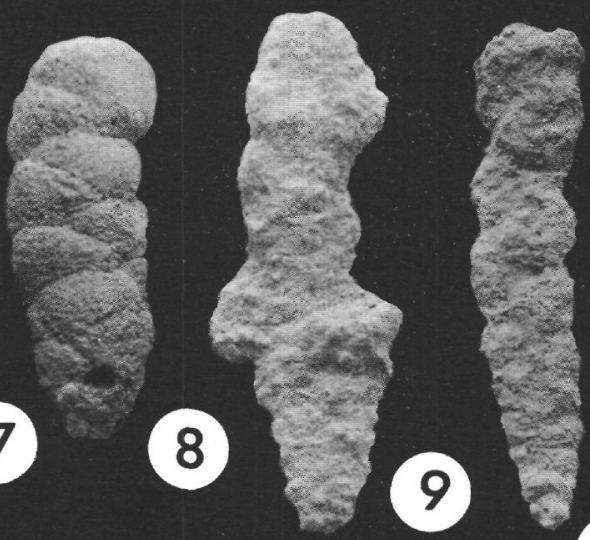

10

12
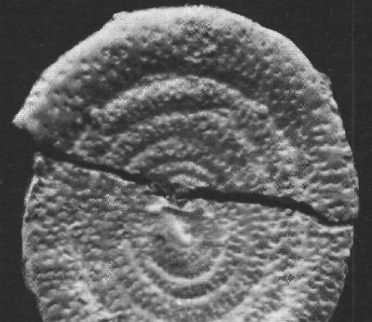

13

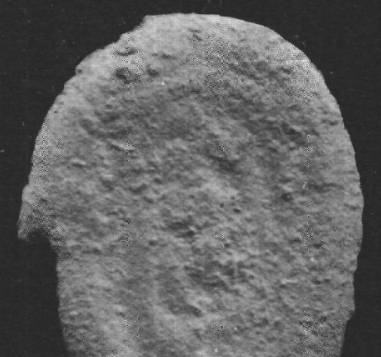

14

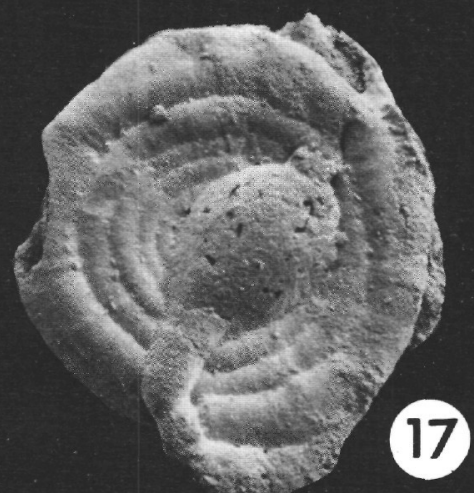




\section{PLATE 6}

Figure $1 \quad$ Hedbergella sp.; 105-11-1, 148-150cm; ×200

Figure 2 Lenticulina ouachensis ouachensis (Signal); 105-18-6, $1416 \mathrm{~cm} ; \times 200$

Figures 3-6 Serpulids; 101A-10-1，125-127cm; 3, $4 \times 240 ; 5$ $\times 600 ; 6 \times 1200$. 
PLATE 6
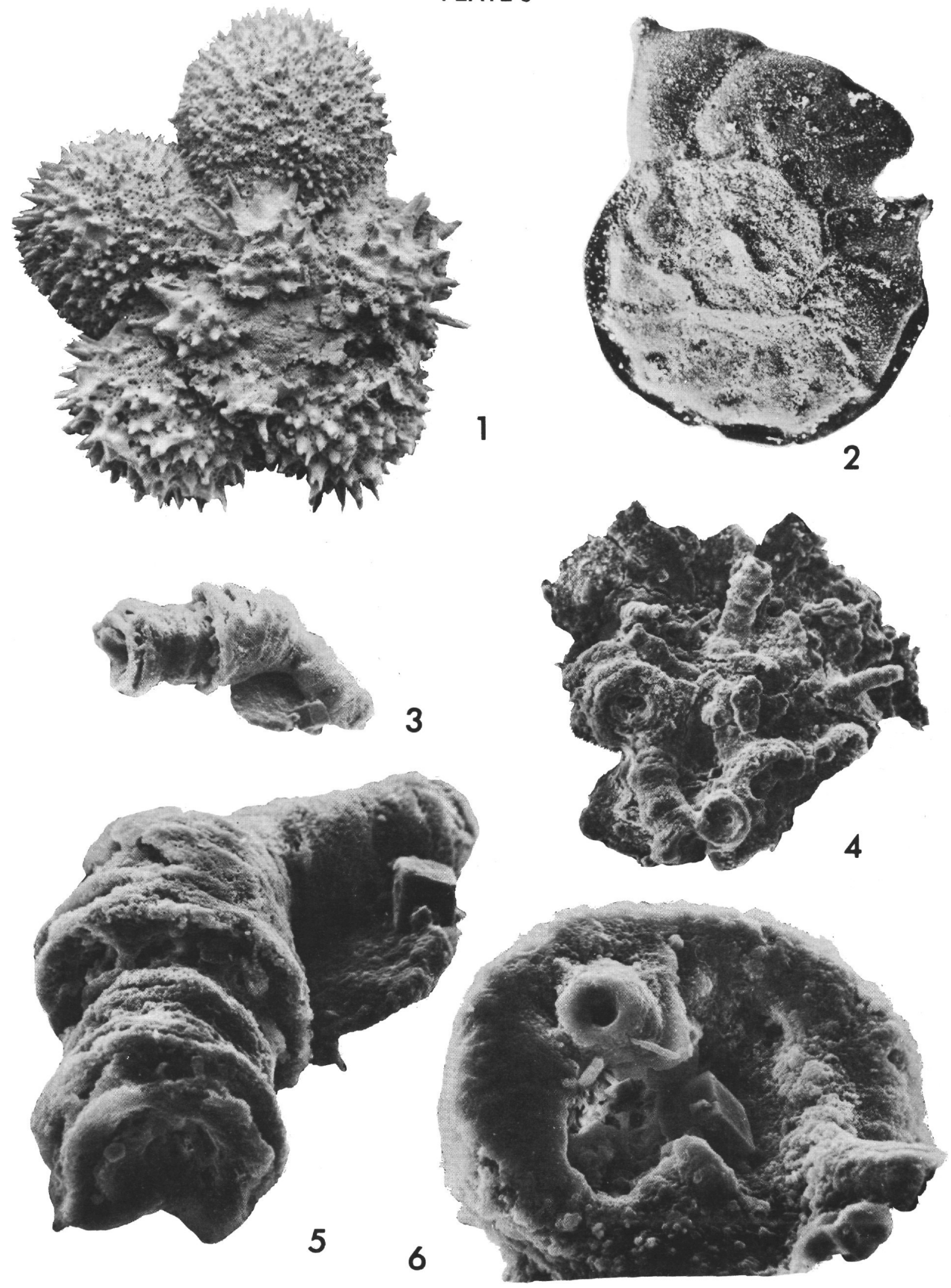


\section{PLATE 7}

Figure 1 "Globigerina helvetojurassica" Haeusler; 105-37-2, $35-57 \mathrm{~cm} ; \times 80$

Figure 2-4 "Stomiosphaera"; 105-23-2, 8-10cm; 2, $3 \times 200 ; 4$ $\times 500$.

Figure 5 Calpionellopsis sp. aff. C. simplex (Colom); 100-1-5, $68-70 \mathrm{~cm} ; \times 200$

Figure 6 Calpionellopsis sp. aff. C. oblonga (Colom); 100-1-5, $68-70 \mathrm{~cm} ; \times 200$

Figures 7, 11 Remaniella sp. aff. R. cadischiana (Colom); 100-1-5, $68-70 \mathrm{~cm} ; 7 \times 200 ; 11 \times 500$

Figure 8 Calpionella sp. aff. C. elliptica Cadisch; 100-1-5, $67-69 \mathrm{~cm} ; \times 200$

Figures 9, 12 Calpionella sp. aff. C. alpina Lorenz; 100-1-5, $67-69 \mathrm{~cm} ; 9 \times 200 ; 12 \times 500$

Figure 10 Tintinnopsella sp. aff. T. carpathica Murgeanu and Filipescu; 100-1-5, 67-69cm; ×200 


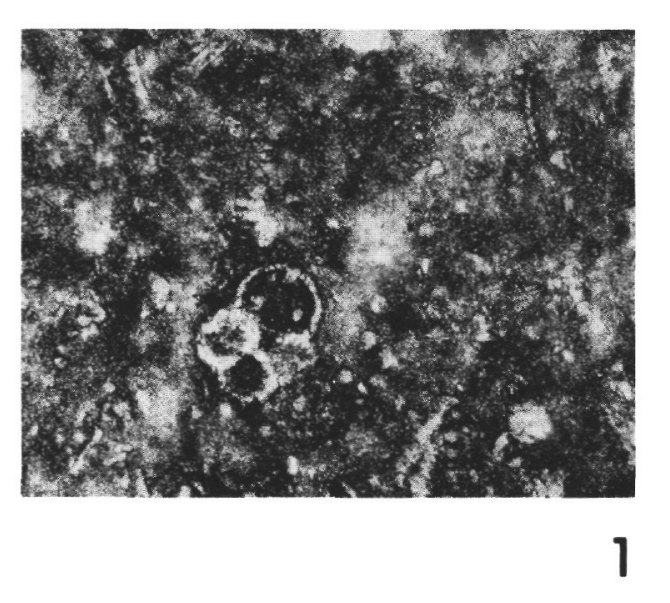

\section{PLATE 7}

1
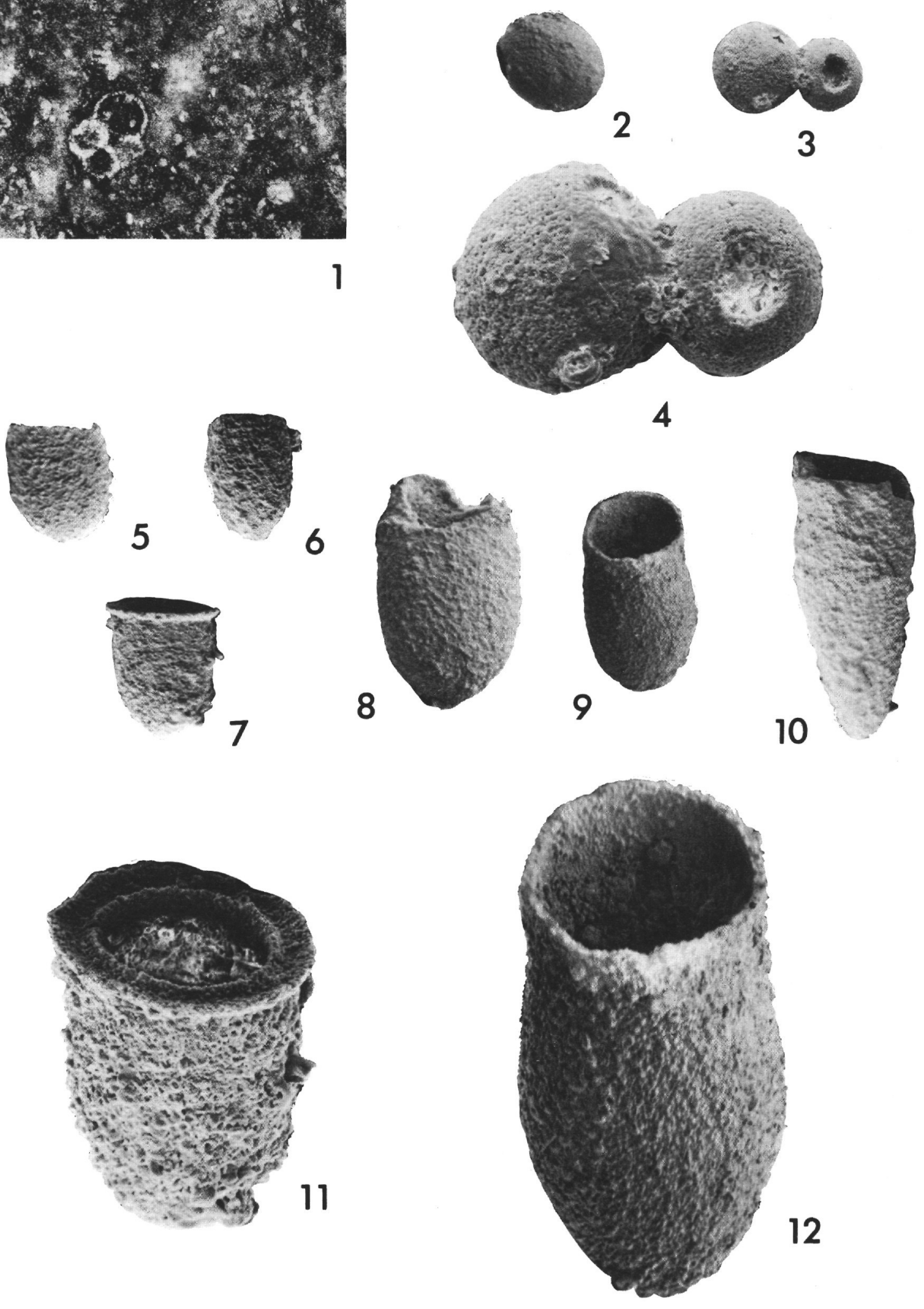


\section{PLATE 8}

Figure $1 \quad$ Surface of "Stomiosphaera", same specimen as Plate 7, Figure 4; X2000

Figures 2, 4 Surface of Calpionella sp. aff. C. elliptica Cadisch, same specimen as Plate 7, Figure $8 ; 2 \times 1000 ; 4$ $\times 2000$

Figure 3 Surface of Remaniella sp. dII. $R$. cadischiana (Colom), same specimen as Plate 7, Figures 7, 11; $\times 2200$ 
PLATE 8
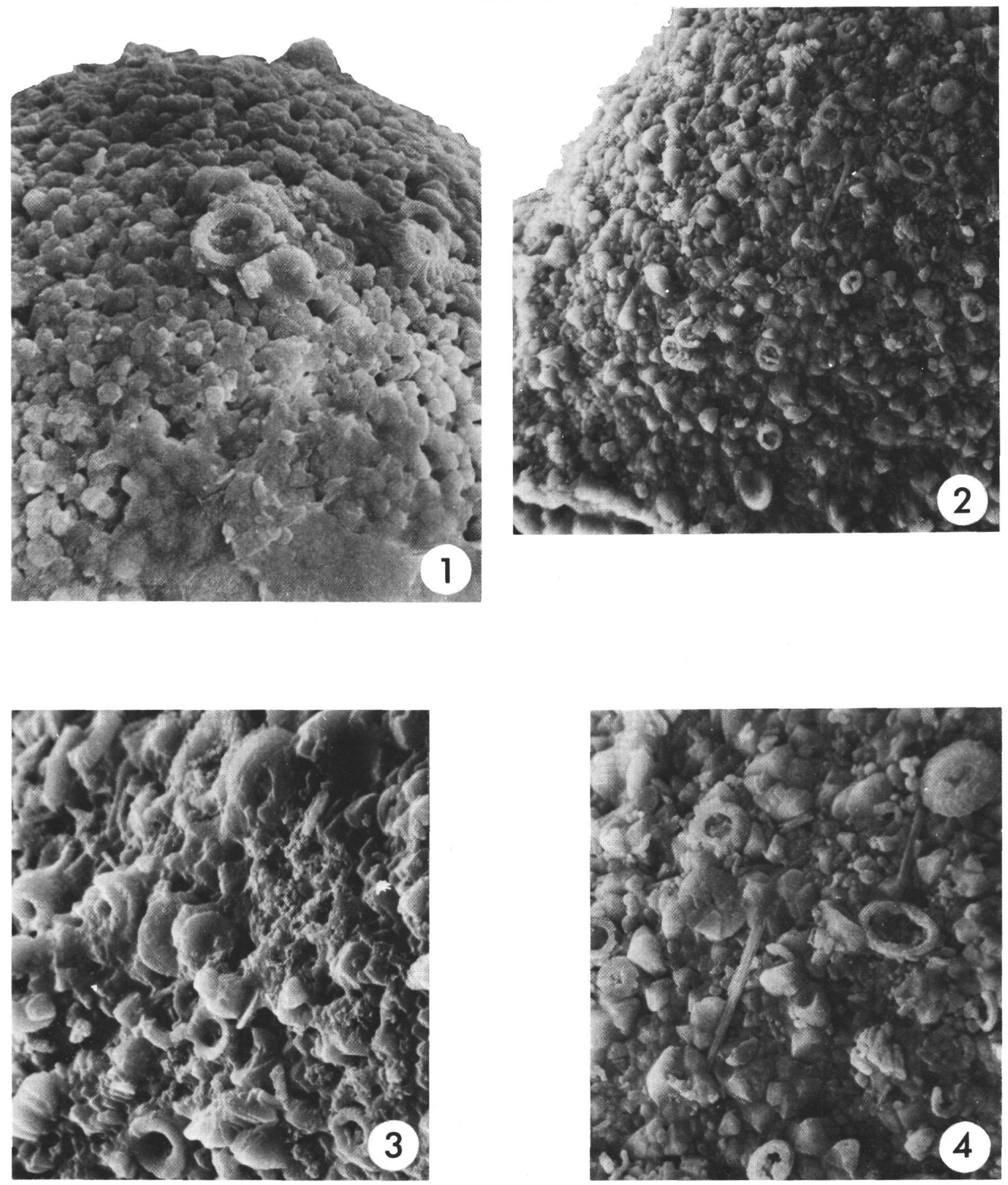